\title{
Revised minimal standards for description of new species of the class Mollicutes (division Tenericutes)
}

\author{
Correspondence \\ Daniel R. Brown \\ BrownD@mail.vetmed.ufl.edu
}

\author{
Daniel R. Brown, ${ }^{1}$ Robert F. Whitcomb ${ }^{2}$ and Janet M. Bradbury ${ }^{3}$ \\ ${ }^{1}$ Department of Infectious Diseases and Pathology, College of Veterinary Medicine, \\ University of Florida, Gainesville, FL 32610-0880, USA \\ ${ }^{2}$ Collaborator, Vegetable Laboratory, Beltsville Agricultural Research Center, US Department of \\ Agriculture, Beltsville, MD 20705, USA \\ ${ }^{3}$ Department of Veterinary Pathology, University of Liverpool, Leahurst, Neston, CH64 7TE, UK
}

Minimal standards for novel species of the class Mollicutes (trivial term, mollicutes), last published in 1995, require revision. The International Committee on Systematics of Prokaryotes Subcommittee on the Taxonomy of Mollicutes proposes herein revised standards that reflect recent advances in molecular systematics and the species concept for prokaryotes. The mandatory requirements are: (i) deposition of the type strain into two recognized culture collections, preferably located in different countries; (ii) deposition of the 16S rRNA gene sequence into a public database, and a phylogenetic analysis of the relationships among the $16 \mathrm{~S}$ rRNA gene sequences of the novel species and its neighbours; (iii) deposition of antiserum against the type strain into a recognized collection; (iv) demonstration, by using the combination of 16S rRNA gene sequence analyses, serological analyses and supplementary phenotypic data, that the type strain differs significantly from all previously named species; and (v) assignment to an order, a family and a genus in the class, with an appropriate specific epithet. The 16S rRNA gene sequence provides the primary basis for assignment to hierarchical rank, and may also constitute evidence of species novelty, but serological and supplementary phenotypic data must be presented to substantiate this. Serological methods have been documented to be congruent with DNA-DNA hybridization data and with 16S rRNA gene placements. The novel species must be tested serologically to the greatest extent that the investigators deem feasible against all neighbouring species whose $16 \mathrm{~S}$ rRNA gene sequences show $>0.94$ similarity. The investigator is responsible for justifying which characters are most meaningful for assignment to the part of the mollicute phylogenetic tree in which a novel species is located, and for providing the means by which novel species can be identified by other investigators. The publication of the description should appear in a journal having wide circulation. If the journal is not the International Journal of Systematic and Evolutionary Microbiology, copies of the publication must be submitted to that journal so that the name may be considered for inclusion in a Validation List as required by the International Code of Bacteriological Nomenclature (the Bacteriological Code). Updated informal descriptions of the class Mollicutes and some of its constituent higher taxa are available as supplementary material in IJSEM Online.
Abbreviations: DDH, DNA-DNA hybridization; DF, deformation; Gl, growth inhibition; IF, immunofluorescence; MI, metabolism inhibition.

D.R.B. and J.M.B. are respectively Secretary and Chair of the International Committee on Systematics of Prokaryotes Subcommittee on the Taxonomy of Mollicutes.

Updated informal descriptions of the class Mollicutes and some of its constituent higher taxa are available as supplementary material with the online version of this paper.

\section{Introduction}

In 1967, the International Committee on Systematic Bacteriology (ICSB) Subcommittee on taxonomy of Mycoplasmatales provided general guidelines for naming species of mollicutes (ICSB Subcommittee on the Taxonomy of Mycoplasmatales, 1967). In 1972, those guidelines were strengthened and published in the form of minimal standards for description of mollicute species (ICSB Subcommittee on the Taxonomy of Mycoplasmatales, 
1972). That document was revised in 1979 and 1995 (ICSB Subcommittee on the Taxonomy of Mollicutes, 1979, 1995). Since the last revision of the minimal standards document, many new methods have been introduced into mollicute systematics, mandating a further revision. When the last minimal standards were published, $16 \mathrm{~S}$ rRNA gene sequence analysis had begun to be used as a definitive indicator of the taxonomic placement of mollicutes. Today, this method has become the benchmark technique for assessment of natural relationships among all microbes (Woese, 1987). The most significant change in this new revision of the minimal standards is the promotion of $16 \mathrm{~S}$ rRNA gene sequencing to mandatory status, and strong reliance on it to determine hierarchical placement of mollicute species. This character, first applied to mollicutes by Woese et al. (1980), was the subject of a major analysis by Weisburg et al. (1989) in which a distance algorithm was used for phylogenetic reconstructions of mollicute phylogeny. Mollicute trees were later reconstructed using improved neighbour-joining (Maniloff, 1992; Johansson \& Pettersson, 2002) and maximum-parsimony (Gundersen et al., 1994; Gasparich et al., 2004) algorithms to interpret an expanding database of $16 \mathrm{~S}$ rRNA gene sequences. The status of the 16S rRNA gene sequence as a taxonomic tool for mollicutes was elevated to primacy by the extensive work of K.-E. Johansson and his colleagues on Mycoplasma and Acholeplasma (Johansson \& Pettersson, 2002), Gasparich et al. (2004) on Spiroplasma and Tom Knight (http://www.broad.mit.edu/annotation/ microbes/mesoplasma_florum/background.html) on Spiroplasma and the Entomoplasmataceae.

\section{The species concept in Mollicutes}

The first step in proposing minimal standards for new species descriptions is to define the word 'species'. The nature of bacterial species has received considerable attention in recent years (Rosselló-Mora \& Amann, 2001). The need for a universally applicable concept mandates a conservative, practical approach. Wayne et al. (1987) advocated a phylogenetic classification, defining species as populations of bacteria whose members share more than $70 \%$ genomic similarity as estimated by heterologous DNA-DNA hybridization (DDH) tests with $\Delta T_{\mathrm{m}}<5{ }^{\circ} \mathrm{C}$. Phenotypic characters were expected to agree largely with phylogenetic classification. The level of $\geqslant 70 \%$ $\mathrm{DDH}$ has been obtained with various prokaryotic species over the years (Johnson, 1980, 1994; Love et al., 1985).

The species concept for Mollicutes is compatible with, and is based in part on, the general species concept for other bacteria. From the earliest days of mycoplasmology, species differentiation of mollicutes has been accomplished by serological tests. The diversity of surface antigens in mollicutes ensures that many epitopes are available to be represented in specific antisera. The first serological test to be employed, and the one most commonly used, is the growth inhibition (GI) test (Edward \& Fitzgerald, 1954; Clyde, 1964, 1983). Two other tests, metabolism inhibition
(MI; Taylor-Robinson, 1983; Taylor-Robinson et al., 1966; Williamson \& Whitcomb, 1983) and immunofluorescence (IF; Del Giudice et al., 1967; Gardella et al., 1983; Bradbury, 1998), have been frequently employed for Mycoplasma and Acholeplasma species. The GI and MI tests have been used with Spiroplasma species, but have been largely supplanted by the spiroplasma deformation (DF) test (Williamson et al., 1978, 1979). When evaluated by one or more of these four serological methods, all of which involve surface antigens, most mollicute species exhibit little or no crossreactivity. Thus, failure to cross-react in controlled tests with any of the antisera against previously recognized species provides substantial evidence for species novelty. By the time the Subcommittee first proposed guidelines for species designation (ICSB Subcommittee on the Taxonomy of Mycoplasmatales, 1967), serology had been established as the most important basis for defining mollicute species. The primacy of serology was affirmed in 1972 in the first minimal standards document, and reaffirmed in later revisions (ICSB Subcommittee on the Taxonomy of Mycoplasmatales, 1972; ICSB Subcommittee on the Taxonomy of Mollicutes, 1979, 1995).

Beginning in the late 1960s, DDH was introduced into mycoplasmology (Reich et al., 1966; Somerson et al., 1967). Neimark (1970) used this technique to determine interspecies relationships among Mycoplasma species, noting that relationships suggested by the technique were in good accord with serological data. DDH experiments were subsequently used to define the relationships among the members of the mycoides group (sensu Weisburg et al., 1989; Johansson \& Pettersson, 2002), in defence of the designation of subspecies of Mycoplasma mycoides and Mycoplasma capricolum (Askaa et al., 1978; Bonnet et al., 1993) and to support elevation of 'Mycoplasma agalactiae subsp. bovis' to full species status. The correlation between DDH and serology was also noted with Spiroplasma, and the correlation served in part as a rationale for the designation of serogroups (Junca et al., 1980; Whitcomb et al., 1987). Another series of studies indicated that DDH values and serology were congruent in Acholeplasma as well (Aulakh et al., 1983; Stephens et al., 1983a, b). Those studies revealed surprisingly extensive genomic heterogeneity in Acholeplasma laidlawii and Acholeplasma axanthum. Some strain pairs shared as little as $40 \% \mathrm{DDH}$, differences that in other genera would have justified subdivision of an apparently diverse strain complex into component species. However, no phenotypic or ecological basis was available to support such designations, so the only recourse was to allow the DDH data to defer to the serology supporting the Acholeplasma species designations. In summary, with serology justified as a surrogate for $\mathrm{DDH}$ to define mollicute species in most cases, the cumbersome reassociation technique could be reserved for special cases in which the affinities of closely related or equivocally cross-reactive strains were in question (AbalainColloc et al., 1993; Gasparich et al., 1993).

The introduction of 16S rRNA gene sequence analysis into bacterial systematics provided a third important measure 
of relationships among mollicute species. Although a general relationship exists between DDH values and $16 \mathrm{~S}$ rRNA gene sequence similarities, the relationship is imprecise (Fox et al., 1992; Stackebrandt \& Goebel, 1994; Keswani \& Whitman, 2001; Rosselló-Mora \& Amann, 2001). The phylogenetic separation of group I spiroplasmas (Spiroplasma citri, Spiroplasma insolitum, Spiroplasma kunkelii, Spiroplasma melliferum and Spiroplasma phoeniceum) also presents some difficulties. Pairs of these organisms have 16S rRNA gene similarity coefficients on the order of 0.98-0.99 (Gasparich et al., 2004). In Mycoplasma, one species pair (Mycoplasma gallisepticum and Mycoplasma imitans) has 16S rRNA gene similarity $>0.99$, yet shows only $40 \%$ DDH (Bradbury et al., 1993). In another case, Mycoplasma hominis strains, which are very heterogeneous (some show as little as $50 \%$ intraspecific DDH), have 16S rRNA gene sequences that show similarities $>0.99$ (Christiansen et al., 1987a, b; Christiansen \& Andersen, 1988; Blanchard et al., 1993). Relationships among strains of highly variable species such as those of the group VIII spiroplasma assemblage cannot be determined by $16 \mathrm{~S}$ rRNA gene sequence analysis or 16S$23 \mathrm{~S}$ rRNA intergenic transcribed spacer (ITS) sequence analysis (Regassa et al., 2004). General guidelines were proposed by Stackebrandt \& Goebel (1994) for determining the circumstances in which DDH tests were warranted. Those authors proposed an upper limit of $0.9716 \mathrm{~S}$ rRNA gene similarity as a threshold, which, if exceeded, would indicate a need for DDH tests to determine whether the strain pair should be regarded as members of a single or separate species. It is presumed that the DDH tests would be performed only if the accumulated character set permitted a novel species to be named. For mollicutes, the current minimal standards document would provide the necessary guidelines to make this determination.

In 2002, an ad hoc committee (Stackebrandt et al., 2002) revisited the question of the prokaryote species. They affirmed the usefulness of the criteria set forth by Wayne et al. (1987), including the value of DDH as the most important discriminating trait at the species level, and pronounced the systematics that had ensued from this approach sound. However, the committee ultimately deferred to a species definition proposed by RossellóMora \& Amann (2001). These authors defined a prokaryotic species as 'a category that circumscribes (preferably) a genomically coherent group of individual isolates/strains sharing a high degree of similarity in (many) independent features, comparatively tested under highly standardized conditions'. Although the committee endorsed DDH as the acknowledged standard for species delineation, they refrained from specifying a lower limit of $70 \% \mathrm{DDH}$ for intraspecies strain similarity. Rosselló-Mora and Amann actually went a bit further, specifically advising: 'Do not use values of $70 \%$ similarity (or $5^{\circ} \mathrm{C} \Delta T_{m}$ ) as absolute limits for circumscribing the species. The current concept allows more relaxed DNA-DNA similarity frontiers, and an internal genomic heterogeneity is permitted.' They urged that a sine qua non requirement for a bacterial species be its coherence as a cluster, even if the encompassed diversity was such that some strain pairs in the cluster showed $<70 \% \mathrm{DDH}$. This principle was recently confirmed and expanded (Rosselló-Mora, 2006).

DDH experiments are commonly regarded as laborious, and there is a practical limit on the number of comparisons that can be done. Acknowledging this, the ad hoc committee (Stackebrandt et al., 2002) proposed that tests other than those involving DNA similarities were appropriate for descriptions of bacterial species, as long as they were consistent with DDH data. Unfortunately, there is no genomic test in place today which could serve this purpose. However, the experience of mycoplasmologists over the nearly 40 years of research during which DDH and serology have been compared is sufficient to establish the essential congruence of serology and DDH (Reich et al., 1966; Somerson et al., 1967; Neimark, 1970; Askaa et al., 1978; Junca et al., 1980; Bové et al., 1982, 1983; Aulakh et al., 1983; Stephens et al., 1983a, b; Abalain-Colloc et al., 1993; Bonnet et al., 1993; Gasparich et al., 1993). Serology is an established procedure which serves effectively as a proteomic surrogate for genomic DDH. The practice of mollicute taxonomists in using the combination of $16 \mathrm{~S}$ rRNA gene sequence analyses, DDH, serology and supplementary phenotypic data to propose novel species is thus consistent with the most recently revisited standards of the microbial systematics community (Stackebrandt et al., 2002).

\section{Steps in the characterization of mollicutes}

Early steps in the discovery and characterization of a novel species provide important insights into the organism's biology. Although some procedural details may be taxonspecific, most are applicable to all putative species. Features such as absence of reversion to walled cells, ability to pass ultrafilters, colony morphology and sterol requirement, listed as mandatory tests in the previous minimal standards document (ICSB Subcommittee on the Taxonomy of Mollicutes, 1995), are almost always explored during the early processing of all strains. These tests, which formerly provided important evidence for assignment to higher taxic levels, have now been largely supplanted by the extensive use of $16 \mathrm{~S}$ rRNA gene sequence analyses. However, because these procedures provide supplementary evidence for taxonomic placement, the protocols employed should be included in species descriptions (Stackebrandt et al., 2002).

\section{(i) Culture media}

Many mollicutes are discovered by using standard media, but the availability of a new medium may facilitate cultivation of novel mollicutes. It is common for culture medium variations to be employed in the course of the discovery and characterization process. One of the first variations to be used in early cultural studies of non-helical 
mollicutes will be one that is serum-free. The first indication that a newly isolated mollicute represents an Acholeplasma species often comes by finding that the organism is able to grow sustainably in serum-free media. However, apparent growth in serum-free media can be deceiving (Whitcomb, 1977; Whitcomb et al., 1997). Some mollicutes require very low levels of sterol for growth, which may be supplied in the passage volume when the cultures are passaged (Razin \& Tully, 1970). Extended passage in sterol-free media is required for a definitive determination. Conversely, slowly growing acholeplasmas may fail to grow in serum-free media.

\section{(ii) Preliminary identification}

The first indication that a strain represents a novel species may be provided by serological screening for other mollicutes associated with the habitat of origin. The definition of habitat is the responsibility of the investigator, who is in a position to predict which known mollicute species may occur, given the circumstances of the isolation. In initial comparisons, the strain should be tested to the extent deemed feasible by the investigator with antisera to all mollicutes known to occur in that habitat. If there are no other known mollicutes in the association, it is logical to proceed directly to cloning. Alternatively, preliminary identification can be by PCR and DNA sequencing using primers specific for eubacterial $16 \mathrm{~S}$ rRNA genes (Johansson et al., 1998) or the 16S-23S ITS region (Maidak et al., 1997). If a simple BLAST search suggests that the $16 \mathrm{~S}$ rRNA gene sequence of an isolate may be unique, a similarity matrix (Felsenstein, 1993) relating the candidate strain to its closest neighbours should be constructed. Usually, this will involve species with $>0.94$ 16S rRNA gene sequence similarity. This matrix will suggest an assemblage of related species that should be examined for serological crossreactivities. These important steps guard against lost time and effort that might be spent studying a strain that is merely an unrecognized representative of a well-known species.

\section{(iii) Triple cloning}

A pure culture is essential for determinative studies. Original isolates in many instances are not only mixtures of allelic variants, clones of surviving mutants or cells exhibiting one or another form controlled by a genetic switch, but may also be mixtures of as many as three or more distinct species (Whitcomb \& Hackett, 1996). For this reason, cloning of mollicute species is essential. Cloning begins with filtration of a broth culture through a filter with pore sizes that retain clumps (Tully, 1983a). With many mollicutes, this is accomplished by the use of 300 or $450 \mathrm{~nm}$ filters but, with group VIII spiroplasmas and a few other mollicutes, a $220 \mathrm{~nm}$ filter should be used. The filtrate and dilutions of it are then cultured on solid medium and an isolated colony is subsequently picked from a plate on which only a few colonies have developed.
This colony is used to found a new cultural line, which is then expanded, filtered, plated and picked twice more. The filtration and cloning steps are performed at least three times to increase the probability that the clone selected to be the type strain is derived from a single cell. After the final cloning, several colonies are picked and one of the cultural lines derived from this process is chosen as a representative of the putative novel species. An alternative procedure, the limiting dilution method (Fazekas de St Groth, 1982), is now used universally in spiroplasma research. Cloning by this method is performed in liquid media (Whitcomb \& Hackett, 1987) in which aliquots of diluted culture are dispensed onto microtitre plates. At some limiting dilution, a microtitre plate will have only a few isolated wells that support organismal growth. Organisms from these wells are 'picked' and, as in solid medium cloning, one of the cultures grown from single wells is chosen as a representative of the putative novel species. All but a few known Spiroplasma species have been cloned by this method.

\section{(iv) Selection of a representative strain}

No single strain can embody all of the characters present in the entire cluster of strains that the species name represents. During the early course of cultural passages, some characters may be lost. These include pathogenicity (Williamson \& Whitcomb, 1975; Bové, 1997) and/or the ability to negotiate biological passage through one or more hosts (Wayadande \& Fletcher, 1995; Fletcher et al., 1998). Such losses, which can occur in fewer than 50 passages, may be inevitable. A possible consequence is that a type strain of a pathogenic mollicute may lose its ability to incite the disease that accounted for its discovery. Because some characters of the wild-type of mollicute species tend to be lost easily during passage in vitro, careful observation of organismal morphology and behaviour during early cultivation is essential. Although such characters cannot be documented by the type strain, they are features of the cluster represented by the type and should be meticulously documented. For this reason, cultures from early passages should be preserved periodically by both lyophilization and freezing at $-70{ }^{\circ} \mathrm{C}$ (Yugi et al., 1973; FAO/WHO Working Group, 1974; Raccach et al., 1975; Leach, 1983). It is common to observe a shift in antigenic properties during early passages of an isolate. This change may reflect resolution of a mixed culture or may be due to shifts in the antigenicity of surface epitopes (Wise et al., 1992; Wise, 1993; Rosengarten \& Yogev, 1996). The type strain may or may not retain the ability to switch from one of these variants to another (Watson et al., 1990, 1993; Persson et al., 2002). The strain may retain the potential for further chromosomal modification as profound as a change, usually a reduction, in genome size (Ye et al., 1995). In spiroplasma lineages, integrated plasmid and viral DNA (Renaudin \& Bové, 1994) and gene duplications (Nur et al., 1987; McIntosh et al., 1992) render the species prone to chromosomal modification during extended cultural 
passage. Passage can also result in the loss of free-replicating plasmids (Berho et al., 2006). For those reasons, it is especially important to monitor the changes that occur during cultural passage of citri-mirum group spiroplasmas. However, no matter how early in the passage history one attempts to document the genetic content of the isolated species, one cannot document what is not present, i.e. additional genetic components of other lineages that may exist under the rubric connoted by the specific epithet. It is reasonable to expect that a core set of genes represented by the type is likely to be present in all of the lineages of the novel species (Himmelreich et al., 1997; Lan \& Reeves, 2001). Definition of the genes that constitute this core can presently be accomplished only ex post facto by genome annotation (Himmelreich et al., 1997; Pollack, 1997; Dandekar et al., 2000). Thus, the chosen type, imperfect though it may be, should represent the investigator's best effort to select a genotype that has a good likelihood of being genetically stable, and represents the bacterial wild-type to the greatest extent possible. The designation of a single type specimen is in concordance with general practice in systematic biology of eukaryotes (Mayr, 1970), in which it is required that a holotype be designated (Winston, 1999). The bacterial type strain (in a sense, a holotype) is designated by a superscript ' $T$ '. For unculturable strains, a reference source which can be maintained, propagated or permanently stored should be cited by a superscript ' $R$ '.

\section{(v) Number of strains}

During the course of a study, investigators sometimes accrue multiple isolates or strains. It may be possible to isolate multiple strains from a particular host or habitat in a single geographical locality, and genotypes may differ to some extent in other geographical localities. Additional strains can be thought of as paratypes, even though, in general systematics, paratypes are more often members of an initial 'series' taken from the same geographical locality. In the original minimal standards document (ICSB Subcommittee on the Taxonomy of Mycoplasmatales, 1972), two strains were required for characterization of a novel mollicute species. However, in 1980 the Subcommittee decided that only a single strain should be required for species characterization (Whitcomb, 1984a, b). Although the International Committee on Systematics of Prokaryotes (ICSP) did not act on a proposal by Christensen et al. (2001) to require characterization of no fewer than five strains in species descriptions of bacteria, as many strains of the candidate species as the investigators deem feasible should be studied during characterization (Stackebrandt et al., 2002). Additional strains usually need not be studied as exhaustively as the type strain, but they should be documented by at least one robust test. The investigators should describe briefly the status of any additional lyophilized specimens believed to be part of the microbial population represented by the type strain. Many culture collections are unwilling to accept deposits of material other than the type. However, the International
Organization for Mycoplasmology (IOM) Culture Collection presently located at Purdue University (West Lafayette, IN, USA) will accept a reasonable number of lyophilized samples of mollicute strains that document different stages of the research process for a given species.

\section{(vi) Colony morphology}

Non-motile mollicutes, or species with only gliding motility, tend to form umbonate ('fried egg-type') colonies on solid media. These are generally noted in the process of cloning non-helical mollicutes. The size and morphology of spiroplasma colonies are variable among species, but a common feature is that satellite colonies are often observed. Because there is no 'typical' colony morphology in Spiroplasma, colony morphology need not be demonstrated for putative species of that genus. Under some circumstances, spiroplasmas do form umbonate colonies on solid media. These colonies are an important indication that the motility of the strain is impaired or that the strain is completely nonmotile. Umbonate colonies of motile species may sometimes be induced by using exceptionally hard agar media, but there is no taxonomic significance to this observation.

\section{(vii) Cellular morphology}

It is important to examine the morphology of a candidate species by light microscopy at the outset of characterization and at various stages during its cultural history. The presence of helical cells throughout the isolation and characterization indicates that the organism, which will have survived continuous exposure to penicillin (ruling out spirochaetes or other helical walled bacteria), is a spiroplasma. Some Spiroplasma species form helices only in certain phases of growth (Gasparich et al., 2004). The variations in helicity of spiroplasmas are important characters and must be fully described. Species of Mycoplasma are usually observed by dark-field or phase-contrast microscopy, but their morphology is so variable that the variability itself is considered a taxonomic character (Freundt, 1955). If a putative novel species is assigned through $16 \mathrm{~S}$ rRNA gene sequence analysis to a recognized mollicute clade, all of whose members have been demonstrated to be wall-less, it is not mandatory to prove the status of its limiting membrane by thin-section electron microscopy. However, if a putative novel species is a member of a group known to possess cytoskeletal features, it is necessary to define the complexities of its outer limiting structure. Gliding motility (Bredt, 1979) may be inapparent or may be lost in early passages. For this reason, it is not necessary to make exhaustive attempts to demonstrate motility of Mycoplasma species. In contrast, the motility of Spiroplasma species can be readily discerned by dark-field microscopy.

\section{(viii) Optimum growth temperature}

The optimum growth temperature of a mollicute reflects the usual habitat of the organism. Most Mycoplasma 
species grow best at $37{ }^{\circ} \mathrm{C}$, reflecting their association with homeothermic ('warm-blooded') vertebrates (Tully et al., 1993). Growth at low temperatures is not known or suspected to be a feature of the ecology of Mycoplasma, 'Candidatus Mycoplasma' or Ureaplasma species isolated from homeothermic vertebrates. The lower part of the permissive temperature range of Mycoplasma species isolated to date from poikilothermic ('cold-blooded') fish and reptiles is only $20-25{ }^{\circ} \mathrm{C}$, although the hosts involved were from temperate or subtropical environments. The investigators will be in the best possible position to justify the growth temperature range they test, based on circumstances of primary isolation. Members of the Entomoplasmatales, including species of Spiroplasma, Mesoplasma and Entomoplasma, and some members of the Acholeplasmatales usually grow best at $30-32{ }^{\circ} \mathrm{C}$. A few spiroplasmas grow well at $37^{\circ} \mathrm{C}$, but most have optima below this temperature. Procedures for assessing optimum temperature and temperature range of mollicutes have been described (Konai et al., 1996). In general, the ability of members of the Entomoplasmatales to grow at temperatures from 10 to $41{ }^{\circ} \mathrm{C}$ should be assessed. The growth rate in doubling time can be readily measured by statistical analysis of growth patterns when the temperature requirements are determined (Konai et al., 1996).

\section{(ix) Aerobiosis and anaerobiosis}

Many mollicutes are facultative anaerobes. Some mollicute species can be isolated much more readily under anaerobiosis. Mollicute species, even though they may be much more readily isolated under anaerobic conditions, can be adapted to grow reasonably well under aerobic conditions. Mollicutes that have a strict requirement for anaerobic environments and that exhibit sensitivity to oxygen are classified in the Anaeroplasmataceae, the single family in the order Anaeroplasmatales (Robinson, 1983).

\section{(x) Additional tests}

Supporting information useful for mollicute classifications at all taxonomic levels may be obtained from tests other than those mandated herein. For example, sensitivities to rifampicin (Gadeau et al., 1986; Pellegrin et al., 1990; Gaurivaud et al., 1996), digitonin (Freundt et al., 1973; Tully, 1983c) or amphotericin B (Rottem, 1972) characterize some taxa. Tests that detect $\alpha$-D-glucosidase (Williams \& Wittler, 1971; Rose \& Tully, 1983), benzyl viologen reduction (Pollack et al., 1996a) or adsorption of erythrocytes to colonies on solid medium (Manchee \& Taylor-Robinson, 1968; Aluotto et al., 1970; Gardella \& Del Giudice, 1983) are of interest in some species. PAGE of cellular proteins (Razin, 1968; Rodwell \& Rodwell, 1978; Mouches et al., 1982, 1983; Saillard et al., 1990) may be an effective technique for special interspecies comparisons. Such data should be reported if they are particularly informative in any respect known to the investigators. It is up to the community of investigators to discover and justify which characters are most meaningful for classification of mollicutes. Additional tests may be included in future standards after they have been shown to be useful in the class.

\section{(xi) Confirmation of novelty}

Initial serological indications of the identity of a putative novel mollicute should be confirmed by testing the cloned strains with the antisera used in the initial screening. Confirmatory serological tests are a defence against time and other resources being spent on an originally inapparent strain of a known species, a mixture of two or more known species or a serovar that emerged during the cloning process. If the initial discovery was through partial characterization of the 16S rRNA gene or 16S-23S ITS region, such as by restriction endonuclease fingerprinting (Stakenborg et al., 2005), amplified fragment length polymorphism (Hong et al., 2005) or partial sequencing, then, at a minimum, the DNA sequence spanning all variable regions (Woese, 1987) of the 16S rRNA gene must be confirmed for the cloned strains.

\section{(xii) Genomic and genetic analyses}

Genome sizes differ tremendously among Spiroplasma, Mycoplasma and Acholeplasma, ranging from about 580 to $2200 \mathrm{kbp}$ (Neimark \& Carle, 1995). The value of genome size for taxonomy of mollicutes (Bak et al., 1969) was considered by some to be reduced when it was discovered that the sizes vary continuously (Pyle et al., 1988; Neimark \& Lange, 1990; Barlev \& Borchsenius, 1991; Carle et al., 1995) rather than bimodally, as once thought. Yet, because genome sizes are discrete, they provide a distinctive character for morphometric analysis. Mollicute genome sizes can be determined more easily and accurately with PFGE (Pyle et al., 1988; Neimark \& Lange, 1990) than by renaturation kinetics (Carle \& Bové, 1983). When using this technique, a summation of fragment sizes from PFGE of a related species whose genome size is known precisely from whole genome sequencing should be compared to the value derived for the new genome as a measure of accuracy. Earlier minimal standards recommended that the base composition ( $\mathrm{G}+\mathrm{C}$ content, mol $\%)$ of chromosomal DNA be determined for each novel species, but there are frequent non-significant (homoplasic) overlaps in the values. The UGA codon usage appears to offer a sharp distinction between higher mollicute taxa (Yamao et al., 1985; Renaudin et al., 1986; Inamine et al., 1990; Citti et al., 1992; Navas-Castillo et al., 1992). Members of the Mycoplasmatales and Entomoplasmatales, so far as is known, utilize both UGA and UGG as tryptophan (W) codons, while only UGG encodes $\mathrm{W}$ in members of the Acholeplasmatales and Anaeroplasmatales and phytoplasmas. However, data are available for only a few species, so the universality of this distinction remains to be established. DDH data provided a definitive test for the status of partially related strains (Johnson, 1980, 1994; Love et al., 
1985; Wayne et al., 1987; Stackebrandt et al., 2002). Cumbersome and difficult to standardize though it may be, this technique remains an important benchmark in assessment of species status in prokaryote taxonomy (Grimont, 1988; Murray et al., 2001; Stackebrandt et al., 2002). DDH experiments may be necessary particularly when designating subspecies or elevating subspecies to species status (Askaa \& Ernø, 1976; Bradbury et al., 1993; Leach et al., 1993).

\section{Mandatory requirements for description of a novel species of Mollicutes}

In consideration of the foregoing reviews of the species concept and usual steps in characterization of Mollicutes, the following are required for novel species descriptions.

\section{(i) Assignment to genus and phylogenetic placement using 16S rRNA gene sequences}

The hierarchical position of a mollicute can be ascertained with considerable accuracy after the organism is cloned by determining the 16S rRNA gene sequence (Woese, 1987; Weisburg et al., 1989; Maidak et al., 1997). Phylogenetic placements of mollicutes based on 16S rRNA gene sequence analysis are now available for almost all mollicute species (Weisburg et al., 1989; Gundersen et al., 1994; Johansson \& Pettersson, 2002; Gasparich et al., 2004). Usually, a simple BLAST search will place the putative novel species in a genus and, in some cases, associate the organism provisionally with one of the major groups, but BLAST is not suitable for a robust analysis of the phylogenetic position in intragroup clades (Koski \& Golding, 2001). Although analysis of the 16S rRNA gene sequence of the type strain is the minimum requirement, sequencing of this locus from additional strains, preferably isolated from the same habitat as the type strain, is strongly encouraged (Stackebrandt et al., 2002). This can provide confirmation that the candidate strain is indeed associated with that habitat, and it may provide an opportunity for sequence diversity to be demonstrated.

After the sequence of a putative novel species has been determined, a similarity matrix (Felsenstein, 1993) showing the relationship of the candidate strain to its closest neighbours should be constructed. If the putative novel species is included in a matrix of $16 \mathrm{~S}$ rRNA gene sequences from its nearest neighbour taxa in the established clades (Johansson \& Pettersson, 2002; Gasparich et al., 2004), similarity values $<0.94$ will constitute evidence of species novelty. If similarity values $>0.94$ are observed, species novelty must be established by other means. It is the responsibility of the investigator to provide the means by which novel species can be identified by other investigators.

The investigators should produce a cladogram or phylogram depicting the relationships of the species to its nearest neighbours. This is accomplished by analysing the $16 \mathrm{~S}$ rRNA gene similarity matrix with a phylogenetic algorithm.
Although cladists prefer maximum-parsimony (Swofford et al., 1996; Swofford, 1998) or maximum-likelihood (Felsenstein, 1993), many analyses of mollicute phylogeny (Johansson \& Pettersson, 2002) have used neighbourjoining (Saitou \& Nei, 1987), which is widely accepted in microbial systematics (Kämpfer et al., 2003).

Guindon et al. (2005) noted that the development of better likelihood-based approaches, including Bayesian, provides arguably the most successful advance in this area in the last decade. Bayesian analyses of phosphoglycerate kinase sequences including ten mollicutes have been reported (Pollack et al., 2005). Although construction of global phylogenetic trees is beyond the scope of novel species descriptions, sequences from as many established species as the investigators deem meaningful should be included in the analysis. These should include all the species in a cluster indicated by preliminary BLAST comparisons. Broad latitude is given to the investigators to choose outgroup species, but inclusion of sample taxa from several mollicute genera would not be onerous.

With certain strain assemblages (e.g. group VIII spiroplasmas), it may be difficult to establish stable intraspecific taxa as new strains are added to the array. In such cases, it may be wise to regard the assemblage as a single variable species (sensu Rosselló-Mora \& Amann, 2001). Attempts to force a strain assemblage into a rigid template required by any classification scheme, Linnaean or otherwise, may be illadvised and ill-fated. Trees themselves may be interpreted as classifications in which the relationships among nested sets of strains can be freely represented.

In the future, bacterial taxonomy will no doubt focus on multiple loci of the bacterial chromosome (Zeigler, 2003). Some workers have used the 16S-23S ITS region for this purpose. This region, because it is less highly conserved than the flanking genes, has the potential to resolve intraspecific relationships or relationships between closely related putative species (Harasawa et al., 2000; Chalker \& Brownlie, 2004; Regassa et al., 2004). Various proteinencoding genes have been used to make phylogenetic inferences (Toth et al., 1994; Falah \& Gupta, 1997; Gupta, 1998; Teichmann \& Mitchison, 1999; Bébéar et al., 2000; Wolf et al., 2004). However, because $16 \mathrm{~S}$ rRNA gene sequence analysis has provided satisfactory resolution across the entire prokaryotic spectrum (Ludwig et al., 1998), it will probably retain its primacy in the taxonomy of prokaryotes (Ludwig \& Schleifer, 1994, 1999). At the time of preparation of this document, at least ten mollicute genomes have been sequenced (Fraser et al., 1995; Himmelreich et al., 1996; Glass et al., 2000; Chambaud et al., 2001; Sasaki et al., 2002; Papazisi et al., 2003; Jaffe et al., 2004; Minion et al., 2004; Oshima et al., 2004; Westberg et al., 2004), and many more are approaching complete annotation. Genome sequencing is well within the capabilities of current technology (Herrmann, 2002), and the genomes of economically significant species in particular seem certain to be sequenced completely, but it 
is unrealistic at this time to envision that complete genome sequences will ever become available for more than a minor fraction of known mollicute species.

\section{(ii) Serology}

Serology is one of the three pillars upon which mollicute taxonomy is constructed. There are several reasons for this. (i) The mollicute species concept has historically been a serospecies concept. It has been used successfully since the first GI tests (Edward \& Fitzgerald, 1954). (ii) Serology provides a vital link between mollicute taxonomy and general principles of microbial taxonomy based on the congruence of serological results and those obtained by DDH in Mollicutes. (iii) Many mollicutes are not now and never will be studied intensively. Identification of these mollicutes for the foreseeable future requires serological reagents. This is especially true in the Entomoplasmatales, in which the discovery rate of novel species greatly exceeds the capacity to develop replacement genotypic methods. (iv) Because antisera potentially represent indices of many loci, they can provide important phenotypic traits otherwise scarcely available for mollicute systematics.

Antiserum is required to perform serological comparisons to previously described strains, including reciprocal tests, and it may be used efficiently to identify future isolates referable to the novel species. The extensive IOM reagent collection presently at Purdue University is a critical resource for mollicute research and identification and is a primary source of previously developed serological reagents. Investigators who are not familiar with the methodology involved in antiserum production should seek guidance from a mycoplasmologist experienced in the procedures. In particular, the investigator should be aware that the choice of adjuvant to be used for preparing the immunogen is critical and that the time required for specific antibodies to appear in rabbit serum is variable. In some cases, booster injections will be required before the levels of specific antibody required for GI, MI or IF tests are reached. After each test bleed, the antiserum should be tested against its homologous species in each of the protocols the investigators wish to use.

(iia) Directed serological testing. Historically, after cloning was accomplished, confirmation that a strain represented a novel species has been achieved by testing the candidate with (ideally) all mollicute antisera (ICSB Subcommittee on the Taxonomy of Mycoplasmatales, 1972; ICSB Subcommittee on the Taxonomy of Mollicutes, 1979, 1995). As the number of serologically distinct strains increased substantially over the years, means were found to lighten this burden. To determine whether an isolate represented a novel species, the effort involved was reduced by omitting antisera to species excluded by other tests. For example, spiroplasmas readily recognized by their helicity and penicillin insensitivity were not tested with antisera against non-helical mollicutes. Similarly, if a Mycoplasma species fermented glucose, it was tested only with antisera against glucose fermenters. Still, serology has become more and more laborious. The availability of $16 \mathrm{~S}$ rRNA gene sequence data permits directed serological screening. It is usually necessary to test the strain only with antisera to species with $>0.9416 \mathrm{~S}$ rRNA gene sequence similarity. The value of 0.94 defines an approximate clade boundary, and should not be confused with the value of 0.97 suggested by Stackebrandt \& Goebel (1994) as a species frontier which, if exceeded, might require DDH experiments to provide an accurate species circumscription. These will often be located in one of the clusters in published phylogenetic trees (Johansson \& Pettersson, 2002; Gasparich et al., 2004). There is one important caveat to the concept of directed testing. In rare instances, there may be reciprocal cross-reactions in some serological tests between species that are not closely related as indicated by the $16 \mathrm{~S}$ rRNA gene, and presumably therefore not by $\mathrm{DDH}$, e.g. $M$. gallisepticum and Mycoplasma synoviae (Yogev et al., 1989). In such cases, it is also necessary to test the strain with antisera to all species known from the habitat of origin. Even if only a one-way reaction exists, this information will vitally affect the interpretation of test results.

(iib) Reciprocal tests and partial cross-reactivity. If a positive reaction is obtained, it is necessary to perform the reciprocal reaction, since many one-way cross-reactions occur in mollicute serology, especially in Ureaplasma and the apis clade of Spiroplasma. If a negative screening reaction is obtained when a putative novel species is tested with an antiserum to an established species, it is unnecessary to do the reciprocal test, inasmuch as only reciprocal reactions are thought to indicate true relationship (Williamson et al., 1979, 1998). Not infrequently, strains will be encountered that exhibit partial serological crossreactivity. Partial cross-reactions usually suggest that the strain being compared shares a limited amount of DNA similarity with the type ( $<80 \% \mathrm{DDH})$. In such cases, DDH measurements may be required to resolve the status of a candidate strain. Species that are distantly related genetically may show a significant serological cross-reaction. In this case, the misleading serological cross-reaction is one of the important features of a novel species that must be described.

(iic) Species-level tests. Three serological tests have been shown to provide species-level sensitivity for non-helical mollicutes. The GI test is used most frequently (Edward \& Fitzgerald, 1954; Clyde, 1964, 1983; Black, 1973; Poveda \& Nicholas, 1998). If the candidate organism cannot be grown easily on agar, the MI test may be used (TaylorRobinson et al., 1966; Taylor-Robinson \& Berry, 1969). This procedure has been used successfully in serological analyses of Ureaplasma (Robertson \& Stemke, 1979), Spiroplasma (Williamson et al., 1979; Williamson \& Whitcomb, 1983) and Mycoplasma strains. With Spiroplasma, the DF test (Williamson et al., 1978) is universally used. The MI test (Williamson et al., 1979) has served as a second test for spiroplasma species descriptions. With non-helical 
mollicutes, the agar plate IF method can be performed as either a direct or indirect fluorescent antibody test (Del Giudice et al., 1967; Black \& Krogsgaard-Jensen, 1974; Gardella et al., 1983; Bradbury, 1998). In general, the GI, MI and IF tests have yielded congruent results.

(iid) Intra- and interspecific relationships. Other tests provide more sophisticated analyses of interspecies relationships, particularly those in which there is considerable DNA similarity (e.g. spiroplasma subgroups; the mycoides group of Mycoplasma; Mycoplasma bovis and M. agalactiae; $M$. gallisepticum and $M$. imitans). Interspecific relationships between Mycoplasma alkalescens and its allies are revealed by immunodiffusion and growth precipitation tests. These species are closely related members of a single cluster in the hominis group of Mycoplasma (Pettersson et al., 2000). Tests such as agar-gel double diffusion (Lemcke, 1965) and crossed immunoelectrophoresis, which permit visualization of discrete antigen bands, are more specific and may be better suited for the study of interspecies relationships (Archer \& Best, 1980; Archer \& Townsend, 1981; Johansson \& Wróblewski, 1983). Western immunoblot tests have also proved useful for the study of interspecies relationships (Rikihisa et al., 1997; Brown et al., 2006). Serological tests using monoclonal antibodies may be useful at intraspecific levels (Yoshida et al., 2000).

(iie) Number of tests required. Serological testing in mollicutes has classically involved at least two serological methods. However, experience has indicated that, in the vast majority of cases, the serological tests regularly employed have been mutually supportive. Furthermore, because the $16 \mathrm{~S}$ rRNA gene sequence of the new strain will have been determined before definitive serology is performed, it is unlikely that a strain that is simply a member of a previously described species will be mistaken for a strain of novel one. Thus, the use of two or more serological tests should be reserved for cases in which the initial results are ambiguous.

(iif) Polyvalent screening techniques. Recommendations concerning serological techniques are based on an extensive background of use and on a unique record of sensitivity and specificity of these techniques for distinguishing mollicute species. However, some species, e.g. M. hominis (Lin \& Kass, 1974), Mycoplasma iowae (AlAnkari \& Bradbury, 1996) and group VIII spiroplasmas (Regassa et al., 2004), exhibit substantial serological heterogeneity. As a result, an occasional isolate may not react in some serological tests with antiserum to the type strain of its species. For such mollicutes, it is necessary to use an expanded set of antisera as screening reagents. Artificially polyvalent typing antisera have been used extensively in spiroplasma systematics and in certain Mycoplasma studies (Ernø, 1977). Extensive research on multiple chromosomal loci may eventually make it possible to reduce or eliminate the role of serology in identification of important species. For example, Ureaplasma urealyticum (sensu Shepard et al. 1974) was eventually subdivided into two species, each of which can be identified on the basis of multiple chromosomal loci (Robertson et al., 2002). This work and the careful supporting research leading to it (Harasawa et al., 1991; Robertson et al., 1994; Knox et al., 1998; Kong et al., 1999, 2000) is an example of a successful transition from serology to molecular genetics, which now permits refined analyses of ureaplasmas (Kong \& Gilbert, 2004).

\section{(iii) Correlation with phenotype}

After a tentative hierarchical placement has been obtained as a result of 16S rRNA gene sequence and serological analyses, an attempt should be made to assemble phenotypic data to test the assumptions generated by the phylogenetic placement. Properties expected to be consistent with the 16S rRNA gene placement include cellular and colonial morphology, optimum growth temperature and sterol and oxygen requirements. Many of these properties will have been determined to some extent in the course of preliminary characterization.

(iiia) Cellular ultrastructure. Previous versions of the minimal standards document required that electron microscopy be performed to show that the organism is bounded by a single membrane and that it lacks a cell wall (ICSB Subcommittee on the Taxonomy of Mycoplasmatales, 1972; ICSB Subcommittee on the Taxonomy of Mollicutes, 1979, 1995). However, when the 16S rRNA gene sequence of a novel species is determined, the candidate can usually be placed in one of the clusters of published phylogenetic trees of mollicutes (Johansson \& Pettersson, 2002; Gasparich et al., 2004). In the majority of such cases, it can be safely inferred that the organism lacks a cell wall, because others in that cluster will have been shown to be solely membrane-bound. This does not imply that electron microscopy has no value, because it may reveal unusual cellular features such as the presence of virions (Cole, 1979; Renaudin \& Bové, 1994). Further, although placements permitted by the 16S rRNA gene sequence obviate the requirement for electron microscopy for the sole purpose of demonstrating the absence of a cell wall, it is mandatory to describe the ultrastructural details of species that are members of clusters with cytoskeletal features (e.g. all of the clusters of the pneumoniae group and the Mycoplasma sualvi cluster of the hominis group). A flask-shaped morphology is common in these lineages (Trachtenberg, 1998). Other features, such as terminal structures or blebs, must be documented. Cell shape and differentiated structures are best studied by negative staining (Cole, 1983), scanning electron microscopy (Carson \& Collier, 1983) or techniques involving cryofixation of the cells (Henderson \& Jensen, 2006).

(iiib) Substrate metabolism. The species description should give full information concerning formulation of 
the media chosen for primary isolations and extended study, including both medium composition and method of formulation. Any problems associated with growth of the putative novel species in artificial media should be reported. It is important to describe selective inhibitors (Tully, 1983b) included in the media. In particular, insensitivity to penicillin provides important evidence of the lack of a cell wall. With most putative novel species, penicillin insensitivity, in conjunction with 16S rRNA gene sequence data, will be sufficient to infer wall-lessness. The ability of the putative novel species to metabolize relevant substrates should be assessed (Poveda, 1998). Experience has revealed difficulties and pitfalls encountered with metabolic tests performed in complex growth media. One of these pitfalls is the tendency for substances other than the substrate to be metabolized, with a concomitant change in $\mathrm{pH}$. It is advisable to perform metabolic tests in the simplest medium possible. In particular, it is helpful to omit yeast extract and/or serum from the medium. One useful strategy is to replace the serum with bovine serum fraction (Whitcomb, 1983). Repeated subculture in the presence of the substrate may be required in order to detect catabolism of certain substances. It is also essential that tests for $\mathrm{pH}$ change be carefully controlled by observations of uninoculated medium with substrate, inoculated medium without substrate and positive and negative control organisms with known requirements. The temperature and length of incubation used in the test should also be defined.

Mollicutes have diverse metabolic pathways (McElwain et al., 1988; Pollack et al., 1989, 1996b, 1997; Miles, 1992; Pollack, 1992), but the implementation of tests reflecting comparative metabolism of mollicutes has posed many challenges (Pollack et al., 1997). Improvements in test protocols (Miles \& Nicholas, 1998) may now make it possible to utilize certain metabolic characterizations more fully in mollicute taxonomy. Catabolism of substrates which the investigator deems to be of special interest or importance to the putative species or to its neighbours may be included in the species description. For example, utilization of fructose should be determined for plantpathogenic mollicutes (Gaurivaud et al., 2000).

Glucose fermentation. The ability to ferment glucose with the production of acid must be assessed (Aluotto et al., 1970; Edward \& Moore, 1975; Razin \& Cirillo, 1983). This test is especially critical with Mycoplasma species because, in this genus, glucose may or may not serve as a primary energy source (Miles, 1992; Pollack, 1992).

Urea hydrolysis. It is extremely important to determine the ability of non-helical mollicutes from vertebrate urogenital tracts to hydrolyse urea (Razin, 1983). Because Ureaplasma species are occasionally isolated from sites other than the urogenital tract, the possibility that a non-helical mollicute of vertebrate origin is a ureaplasma must be seriously considered. The placement of such an organism in Ureaplasma, however, should be readily accomplished by $16 \mathrm{~S}$ rRNA gene sequence analysis. The inability of Spiroplasma species to utilize urea has been demonstrated for each of the known species.

Arginine hydrolysis. The ability of the candidate to hydrolyse arginine with the production of ammonia should be determined (Barile, 1983). Results of this test have been variable and at times confusing (Hackett et al., 1996). A modified test performed with arginine concentrations that range from 2 to $10 \mathrm{~g} \mathrm{l}^{-1}$ is sometimes used, inasmuch as some organisms are inhibited by relatively high concentrations of arginine (Leach, 1976). It should also be emphasized that arginine hydrolysis in some Spiroplasma species can be demonstrated only when glucose or another energy source is supplied at the same time (Townsend, 1976). This can be accomplished by adding small amounts of glucose $(0.1 \%)$ to arginine-containing broth. If the test is positive, an initial decrease in $\mathrm{pH}$ will be followed by an elevation of $\mathrm{pH}$. If test results appear to be negative, it is important to perform repeated subcultures in the presence of arginine. This is especially important if the organism also metabolizes glucose.

\section{(iv) Ecology}

The following kinds of ecological information often obtained in the course of characterization, if known to the investigators, should accompany a species description: (i) circumstances of isolation, including the medium, selective inhibitors and details of filtration procedures used; (ii) common and binomial name of the host; (iii) geographical location of the original isolation, including Global Positioning Satellite coordinates; (iv) data on known interactions between the candidate mollicute and the host, including the status of the mollicute as a pathogen, commensal or epiphyte; and (v) in the case of disease, signs induced and evidence for specific aetiology.

\section{(v) Adherence to taxonomic rules and procedures}

Finally, it is important that workers who propose new taxonomic descriptions for mollicutes have a familiarity with bacterial nomenclature and its specific historical application to the Mollicutes. For example, when naming new Spiroplasma species, workers must assign the novel species a place in the group system, which encompasses both named and putative species (Whitcomb et al., 1987). Investigators should also be familiar with the Rules and Recommendations of the International Code of Nomenclature of Bacteria (Lapage et al., 1992; Trüper, 1996, 1999). A Latin reference that can provide guidance in naming scientific taxa should be consulted (MacAdoo, 1993; Trüper, 2007).

In Mollicutes, the subspecies rank should be reserved for important strains that differ consistently but are too closely 
related, by serological properties and/or $>70 \% \mathrm{DDH}$, to warrant species rank (Johnson, 1980, 1994; Love et al., 1985). The extent of DDH, although recently demoted as an absolute arbiter of species status (Rosselló-Mora \& Amann, 2001), may provide essential justification for promoting a strain group to subspecies status (Leach et al., 1993) or elevation of a subspecies to species rank (Askaa \& Ernø, 1976). A subspecies should not be proposed if serological and supporting phenotypic or ecological evidence is limited or if the strain has few cohorts. For strains that do not merit subspecies designations, temporary use of infrasubspecific ranks (strain, serovar, pathovar, biovar, etc.) is much preferred, since the use of such designations provides more flexibility than Latin tertiary combinations (i.e. subspecies names) and encourages the accumulation of additional data relevant to classification.

Two important alternative classifications of mollicutes other than the hierarchical Linnaean system exist. As mentioned above, 'Candidatus Phytoplasma' organisms are classified in a system maintained by the IRPCM Phytoplasma/Spiroplasma Working Team (2004). In the case of spiroplasmas, the characterization process may be truncated, resulting in the designation of 'group' status (Junca et al., 1980; Williamson et al., 1998).

Many factors other than rRNA gene sequences and/or serology are of potential importance in making taxonomic decisions. Thus, species descriptions and or taxic revisions should always be, to some extent, polyphasic (Colwell, 1970; Rosselló-Mora \& Amann, 2001). Recent rediscoveries of polyphasic taxonomy underscore its importance (Vandamme et al., 1996). No prescription can be given for these tests, because they differ among genera and species. The investigator is responsible for justifying which specifics are most meaningful for the part of the mollicute tree in which a novel species is located. This responsibility is shared by the reviewers and editors who endorse novel species descriptions. Good species descriptions should be polyphasic to the extent that they describe meaningful idiosyncrasies of novel species as well as common parameters. The present document contains a list of procedures that will be common to all species descriptions. The investigator may discover properties of certain organisms that should be documented that would be inappropriate for other species. Failure to document casespecific details known to the investigators should not be excused on grounds that they are not part of the minimal standards, and reviewers of papers should take into consideration the adequacy of descriptions with special respect to the clade or cluster in which the novel species is placed. On the other hand, investigators who have otherwise satisfied the mandatory requirements are not expected to search for as-yet unknown idiosyncrasies on grounds that they would be meaningful if discovered.

In the years following the publication of the first minimal standards documents (ICSB Subcommittee on the Taxonomy of Mycoplasmatales, 1972), adherence to the spirit of the standards has been excellent. Increasing emphasis is being placed on adherence to the standards (Stackebrandt et al., 2002; Kämpfer et al., 2003), and authors should expect manuscripts to be judged in part on fulfilment of the standards, since, after nearly 50 years of conformance, no other standards exist. Investigators are expected to document the procedures they use, for example through the provision for supplementary material in the International Journal of Systematic and Evolutionary Microbiology. It is understood that circumstances vary among mollicute strains and that, in some cases, a particular test or procedure may yield equivocal results. Authors are encouraged to explain briefly the circumstances that prevented recommended tests from being performed. Reviewers and editors are expected to defer to authors who offer such explanations.

\section{Acknowledgements}

This work was supported in part by Public Health Service grants 1R15HG02389-01A1 from the National Human Genome Research Institute and 1R01GM076584-01A1 from the National Institute of General Medical Sciences (D. R. B.).

\section{References}

Abalain-Colloc, M. L., Williamson, D. L., Carle, P., Abalain, J. H., Bonnet, F., Tully, J. G., Konai, M., Whitcomb, R. F., Bové, J. M. \& Chastel, C. (1993). Division of group XVI spiroplasmas into subgroups. Int J Syst Bacteriol 43, 342-346.

Al-Ankari, A.-R. S. \& Bradbury, J. M. (1996). Mycoplasma iowae: a review. Avian Pathol 25, 205-229.

Aluotto, B. B., Wittler, R. G., Williams, C. O. \& Faber, J. E. (1970). Standardized bacteriologic techniques for the characterization of Mycoplasma species. Int J Syst Bacteriol 20, 35-58.

Archer, D. B. \& Best, J. (1980). Serological relatedness of spiroplasmas estimated by enzyme-linked immunosorbent assay and crossed immunoelectrophoresis. J Gen Microbiol 119, 413-422.

Archer, D. B. \& Townsend, R. (1981). Immunoelectrophoretic separation of spiroplasma antigens. J Gen Microbiol 123, 61-68.

Askaa, G. \& Ernø, H. (1976). Elevation of Mycoplasma agalactiae subsp. bovis to species rank: Mycoplasma bovis (Hale et al.) comb. nov. Int J Syst Bacteriol 26, 323-325.

Askaa, G., Ernø, H. \& Ojo, M. O. (1978). Bovine mycoplasmas; classification of groups related to Mycoplasma mycoides. Acta Vet Scand 19, 166-178.

Aulakh, G. S., Stephens, E. B., Tully, J. G., Rose, D. L. \& Barile, M. F. (1983). Nucleic acid relationships among Acholeplasma species. J Bacteriol 153, 1338-1341.

Bak, A. L., Black, F. T., Christiansen, C. \& Freundt, E. A. (1969). Genome size of mycoplasmal DNA. Nature 244, 1209-1210.

Barile, M. F. (1983). Arginine hydrolysis. In Methods in Mycoplasmology, vol. 1, pp. 345-349. Edited by S. Razin \& J. G. Tully. New York: Academic Press.

Barlev, N. A. \& Borchsenius, S. N. (1991). Continuous distribution of mycoplasma genome sizes. Biomed Sci 2, 641-645.

Bébéar, C. M., Grau, O., Charron, A., Renaudin, H., Gruson, D. \& Bébéar, C. (2000). Cloning and nucleotide sequence of the DNA gyrase ( $g y r A)$ gene from Mycoplasma hominis and characterization of 
quinolone-resistant mutants selected in vitro with trovafloxacin. Antimicrob Agents Chemother 44, 2719-2727.

Berho, N., Duret, S. \& Renaudin, J. (2006). Absence of plasmids encoding adhesion-related proteins in non-insect-transmissible strains of Spiroplasma citri. Microbiology 152, 873-876.

Black, F. T. (1973). Modification of the growth inhibition test and its application to human T-mycoplasmas. Appl Microbiol 25, 528-533.

Black, F. T. \& Krogsgaard-Jensen, A. (1974). Application of indirect immunofluorescence, indirect haemagglutination and polyacrylamide-gel electrophoresis to human T-mycoplasmas. Acta Pathol Microbiol Scand [B] Microbiol Immunol 82, 345-353.

Blanchard, A., Yáñez, A., Dybvig, K., Watson, H. L., Griffiths, G. \& Cassell, G. H. (1993). Evaluation of intraspecies genetic variation within the 16S rRNA gene of Mycoplasma hominis and detection by polymerase chain reaction. J Clin Microbiol 31, 1358-1361.

Bonnet, F., Saillard, C., Bové, J. M., Leach, R. H., Rose, D. L., Cottew, G. S. \& Tully, J. G. (1993). DNA relatedness between field isolates of mycoplasma F38 group, the agent of contagious caprine pleuropneumonia, and strains of Mycoplasma capricolum. Int J Syst Bacteriol 43, 597-602.

Bové, J. M. (1997). Spiroplasmas: infectious agents of plants, arthropods and vertebrates. Wien Klin Wochenschr 109, 604-612.

Bové, J. M., Saillard, C., Junca, P., DeGorce-Dumas, J. R., Ricard, B., Nhami, A., Whitcomb, R. F., Williamson, D. \& Tully, J. G. (1982). Guanine-plus-cytosine content, hybridization percentages, and EcoRI restriction enzyme profiles of spiroplasmal DNA. Rev Infect Dis 4 (Suppl.), S129-S136.

Bové, J. M., Mouches, C., Carle-Junca, P., Degorce-Dumas, F. R., Tully, J. G. \& Whitcomb, R. F. (1983). Spiroplasmas of group I - The Spiroplasma citri cluster. Yale J Biol Med 56, 573-582.

Bradbury, J. M. (1998). Identification of mycoplasmas by immunofluorescence. Methods Mol Biol 104, 119-126.

Bradbury, J. M., Saed Abdul-Wahab, O. M., Yavari, C. A., Dupiellet, J.-P. \& Bové, J. M. (1993). Mycoplasma imitans sp. nov. is related to Mycoplasma gallisepticum and found in birds. Int J Syst Bacteriol 43, 721-728.

Bredt, W. (1979). Motility. In The Mycoplasmas, vol. 1, pp. 141-155. Edited by M. F. Barile \& S. Razin. New York: Academic Press.

Brown, D. R., Demcovitz, D. L., Plourdé, D. R., Potter, S. M., Hunt, M. E., Jones, R. D. \& Rotstein, D. S. (2006). Mycoplasma iguanae sp. nov., from a green iguana (Iguana iguana) with vertebral disease. Int $J$ Syst Evol Microbiol 56, 761-764.

Carle, P. \& Bové, J. M. (1983). Genome size determination. In Methods in Mycoplasmology, vol. 1, pp. 309-311. Edited by S. Razin \& J. G. Tully. New York: Academic Press.

Carle, P., Laigret, F., Tully, J. G. \& Bové, J. M. (1995). Heterogeneity of genome sizes within the genus Spiroplasma. Int J Syst Bacteriol 45, $178-181$.

Carson, J. L. \& Collier, A. M. (1983). Scanning electron microscopy of mycoplasmas. In Methods in Mycoplasmology, vol. 1, pp. 51-55. Edited by S. Razin \& J. G. Tully. New York: Academic Press.

Chalker, V. J. \& Brownlie, J. (2004). Taxonomy of the canine Mollicutes by $16 \mathrm{~S}$ rRNA gene and 16S/23S rRNA intergeneric spacer region sequence comparison. Int J Syst Evol Microbiol 54, 537-542.

Chambaud, I., Heilig, R., Ferris, S., Barbe, V., Samson, D., Galisson, F., Moszer, I., Dybvig, K., Wróblewski, H. \& other authors (2001). The complete genome sequence of the murine respiratory pathogen Mycoplasma pulmonis. Nucleic Acids Res 29, 2145-2153.

Christensen, H., Bisgaard, M., Frederiksen, W., Mutters, R., Kuhnert, P. \& Olsen, J. E. (2001). Is characterization of a single isolate sufficient for valid publication of a new genus or species? Proposal to modify
Recommendation 30b of the Bacteriological Code (1990 Revision). Int J Syst Evol Microbiol 51, 2221-2225.

Christiansen, G. \& Andersen, H. (1988). Heterogeneity among Mycoplasma hominis strains as detected by probes containing parts of ribosomal ribonucleic acid genes. Int J Syst Bacteriol 38, 108-115.

Christiansen, C., Christiansen, G. \& Rasmussen, O. F. (1987a). Heterogeneity of Mycoplasma hominis as detected by a probe for atp genes. Isr J Med Sci 23, 591-594.

Christiansen, G., Andersen, H., Birkelund, S. \& Freundt, E. A. (1987b). Genomic and gene variation in Mycoplasma hominis strains. Isr J Med Sci 23, 595-602.

Citti, C., Marechal, D. L., Saillard, C., Weil, J. H. \& Bové, J. M. (1992). Spiroplasma citri UGG and UGA tryptophan codons, sequence of the two tryptophanyl-tRNAs and organization of the corresponding genes. J Bacteriol 174, 6471-6478.

Clyde, W. A., Jr (1964). Mycoplasma species identification based upon growth inhibition by specific antisera. J Immunol 92, 958-965.

Clyde, W. A., Jr (1983). Growth inhibition tests. In Methods in Mycoplasmology, vol. 1, pp. 405-410. Edited by S. Razin \& J. G. Tully. New York: Academic Press.

Cole, R. M. (1979). Mycoplasma and spiroplasma viruses. Ultrastructure. In The Mycoplasmas, vol. 1, pp. 385-410. Edited by M. F. Barile \& S. Razin. New York: Academic Press.

Cole, R. M. (1983). Transmission electron microscopy. Basic techniques. In Methods in Mycoplasmology, vol. 1, pp. 43-50. Edited by S. Razin \& J. G. Tully. New York: Academic Press.

Colwell, R. R. (1970). Polyphasic taxonomy of bacteria. In Culture Collections of Microorganisms. Proceedings of the International Conference on Culture Collections, Oct (1968), pp. 421-436. Edited by H. Izuka \& T. Hasegawa. Tokyo: University of Tokyo Press.

Dandekar, T., Huynen, M., Regula, J. T.,, Ueberle, B., Zimmermann, C. U., Andrade, M. A., Doerks, T., Sánchez-Pulido, L., Snel, B. \& other authors (2000). Re-annotating the Mycoplasma pneumoniae genome sequence: adding value, function and reading frames. Nucleic Acids Res 28, 3278-3288.

Del Giudice, R. A., Robillard, N. F. \& Carski, T. R. (1967). Immunofluorescence identification of Mycoplasma on agar by use of incident illumination. J Bacteriol 93, 1205-1209.

Edward, D. G. \& Fitzgerald, W. A. (1954). Inhibition of growth of pleuro-pneumonia-like organisms by antibody. J Pathol Bacteriol 68, 23-30.

Edward, D. G. \& Moore, W. B. (1975). A method for determining utilization of glucose by mycoplasmas. J Med Microbiol 8, 451-454.

Ernø, H. (1977). Mycoplasmas: use of polyvalent antisera for identification by indirect immunofluorescence. Acta Vet Scand 18, 176-186.

Falah, M. \& Gupta, R. S. (1997). Phylogenetic analysis of mycoplasmas based on Hsp70 sequences: cloning of the $d n a K$ ( $h s p 70)$ gene region of Mycoplasma capricolum. Int J Syst Bacteriol 47, 38-45.

FAO/WHO Working Group (1974). Preservation of mycoplasmas by lyophilization. World Health Organization working document VPH/ MIC/741. FAO/WHO Programme on Comparative Mycoplasmology Working Group. Geneva: World Health Organization.

Fazekas de St Groth, S. (1982). The evaluation of limiting dilutions assays. J Immunol Methods 49, R11-R23.

Felsenstein, J. (1993). PHYLIP (phylogeny inference package) version 3.5. Distributed by the author. Department of Genome Sciences, University of Washington, Seattle, USA.

Fletcher, J., Wayadande, A., Melcher, U. \& Ye, F. (1998). The phytopathogenic mollicute-insect vector interface: a closer look. Phytopathology 88, 1351-1358. 
Fox, G. E., Wisotzkey, J. D. \& Jurtshuk, P., Jr (1992). How close is close. $16 \mathrm{~S}$ rRNA sequence identity may not be sufficient to guarantee species identity. Int J Syst Bacteriol 42, 166-170.

Fraser, C. M., Gocayne, J. D., White, O., Adams, M. D., Clayton, R. A., Fleischmann, R. D., Bult, C. J., Kerlavage, A. R., Sutton, G. \& other authors (1995). The minimum gene complement of Mycoplasma genitalium. Science 270, 397-403.

Freundt, E. A. (1955). The classification of the pleuropneumonia group of organisms (Borrelomycetales). Int Bull Bacteriol Nomencl Taxon 5, 67-78.

Freundt, E. A., Andrews, B. E., Ernø, H., Kunze, M. \& Black, F. T. (1973). The sensitivity of mycoplasmatales to sodium-polyanetholsulfonate and digitonin. Zentralbl Bakteriol [Orig A] 225, 104-112.

Gadeau, A. P., Mouches, C. \& Bové, J. M. (1986). Probable insensitivity of mollicutes to rifampin and characterization of spiroplasmal DNA-dependent RNA polymerase. J Bacteriol 166, 824-828.

Gardella, R. S. \& Del Giudice, R. A. (1983). Hemagglutination, hemadsorption and hemolysis. In Methods in Mycoplasmology, vol. 1, pp. 379-384. Edited by S. Razin \& J. G. Tully. New York: Academic Press.

Gardella, R. S., Del Giudice, R. A. \& Tully, J. G. (1983). Immunofluorescence. In Methods in Mycoplasmology, vol. 1, pp. 431-439. Edited by S. Razin \& J. G. Tully. New York: Academic Press.

Gasparich, G. E., Saillard, C., Clark, E. A., Konai, M., French, F. E., Tully, J. G., Hackett, K. J. \& Whitcomb, R. F. (1993). Serologic and genomic relatedness of group VIII and group XVII spiroplasmas and subdivision of spiroplasma group VIII into subgroups. Int J Syst Bacteriol 43, 338-341.

Gasparich, G. E., Whitcomb, R. F., Dodge, D., French, F. E., Glass, J. \& Williamson, D. L. (2004). The genus Spiroplasma and its non-helical descendants: phylogenetic classification, correlation with phenotype and roots of the Mycoplasma mycoides clade. Int J Syst Evol Microbiol 54, 893-918.

Gaurivaud, P., Laigret, F. \& Bové, J.-M. (1996). Insusceptibility of members of the class Mollicutes to rifampin: studies of the Spiroplasma citri RNA polymerase $\beta$-subunit gene. Antimicrob Agents Chemother 40, 858-862.

Gaurivaud, P., Laigret, F., Garnier, M. \& Bové, J. M. (2000). Fructose utilization and pathogenicity of Spiroplasma citri: characterization of the fructose operon. Gene 252, 61-69.

Glass, J. I., Lefkowitz, E. J., Glass, J. S., Heiner, C. D. R., Chen, E. Y. \& Cassell, G. H. (2000). The complete sequence of the mucosal pathogen Ureaplasma urealyticum. Nature 407, 757-762.

Grimont, P. A. D. (1988). Use of DNA reassociation in bacterial classification. Can J Microbiol 34, 541-546.

Guindon, S., Lethiec, F., Duroux, P. \& Gascuel, O. (2005). PHYML Online - a web server for fast maximum likelihood-based phylogenetic inference. Nucleic Acids Res 33, W557-W559.

Gundersen, D. E., Lee, I.-M., Rehner, S. A., Davis, R. E. \& Kingsbury, D. T. (1994). Phylogeny of mycoplasmalike organisms (phytoplasmas): a basis for their classification. J Bacteriol 176, 5244-5254.

Gupta, R. S. (1998). Protein phylogenies and signature sequences: a reappraisal of evolutionary relationships among archaebacteria, eubacteria, and eukaryotes. Microbiol Mol Biol Rev 62, 1435-1491.

Hackett, K. J., Clark, E. A., Whitcomb, R. F., Camp, M. \& Tully, J. G. (1996). Amended data on arginine utilization by Spiroplasma species. Int J Syst Bacteriol 46, 912-915.

Harasawa, R., Dybvig, K., Watson, H. L. \& Cassell, G. H. (1991). Two genomic clusters among 14 serovars of Ureaplasma urealyticum. Syst Appl Microbiol 14, 393-396.
Harasawa, R., Hotzel, H. \& Sachse, K. (2000). Comparison of the 16S-23S rRNA intergenic spacer regions among strains of the Mycoplasma mycoides cluster and reassessment of the taxonomic position of Mycoplasma sp. bovine group 7. Int J Syst Evol Microbiol 50, 1325-1329.

Henderson, G. P. \& Jensen, G. J. (2006). Three-dimensional structure of Mycoplasma pneumoniae's attachment organelle and a model for its role in gliding motility. Mol Microbiol 60, 376-385.

Herrmann, R. (2002). Genome structure and organization. In Molecular Biology and Pathogenicity of Mycoplasmas, pp. 157-168. Edited by S. Razin \& R. Herrmann. London: Kluwer.

Himmelreich, R., Hilbert, H., Plagens, H., Pirkl, E., Li, B.-C. \& Herrmann, R. (1996). Complete sequence analysis of the genome of the bacterium Mycoplasma pneumoniae. Nucleic Acids Res 24, 4420-4449.

Himmelreich, R., Plagens, H., Hilbert, H., Reiner, B. \& Herrmann, R. (1997). Comparative analysis of the genomes of the bacteria Mycoplasma pneumoniae and Mycoplasma genitalium. Nucleic Acids Res 25, 701-712.

Hong, Y., Garcia, M., Levisohn, S., Lysynansky, I., Leiting, V., Savelkoul, P. H. M. \& Kleven, S. H. (2005). Evaluation of amplified fragment length polymorphism for differentiation of avian mycoplasma species. J Clin Microbiol 43, 909-912.

ICSB Subcommittee on the Taxonomy of Mollicutes (1979). Proposal of minimal standards for descriptions of new species of the class Mollicutes. Int J Syst Bacteriol 29, 172-180.

ICSB Subcommittee on the Taxonomy of Mollicutes (1995). Revised minimum standards for descriptions of new species of the class Mollicutes (Division Tenericutes). Int J Syst Bacteriol 45, 605-612.

ICSB Subcommittee on the Taxonomy of Mycoplasmatales (1967). Recommendations on nomenclature of the order Mycoplasmatales. Science 155, 1694-1696.

ICSB Subcommittee on the Taxonomy of Mycoplasmatales (1972). Proposal for minimal standards for descriptions of new species of the order Mycoplasmatales. Int J Syst Bacteriol 22, 184-188.

Inamine, J. M., Ho, K.-C., Loechel, S. \& Hu, P. C. (1990). Evidence that UGA is read as a tryptophan codon rather than as a stop codon by Mycoplasma pneumoniae, Mycoplasma genitalium, and Mycoplasma gallisepticum. J Bacteriol 172, 504-506.

IRPCM Phytoplasma/Spiroplasma Working Team (2004). 'Candidatus Phytoplasma', a taxon for the wall-less, non-helical prokaryotes that colonize plant phloem and insects. Int J Syst Evol Microbiol 54, 1243-1255.

Jaffe, J. D., Stange-Thomann, N., Smith, C., DeCaprio, D., Fisher, S., Butler, J., Calvo, S., Elkins, T., FitzGerald, M. G. \& other authors (2004). The complete genome and proteome of Mycoplasma mobile. Genome Res 14, 1447-1461.

Johansson, K.-E. \& Pettersson, B. (2002). Taxonomy of Mollicutes. In Molecular Biology and Pathogenicity of Mycoplasmas, pp. 1-29. Edited by S. Razin \& R. Herrmann. London: Kluwer.

Johansson, K.-E. \& Wróblewski, H. (1983). Characterization of membrane proteins by crossed immunoelectrophoresis. In Methods in Mycoplasmology, vol. 1, pp. 257-267. Edited by S. Razin \& J. G. Tully. New York: Academic Press.

Johansson, K.-E., Heldtander, M. U. \& Pettersson, B. (1998). Characterization of mycoplasmas by PCR and sequence analysis with universal $16 \mathrm{~S}$ rDNA primers. Methods Mol Biol 104, 145-165.

Johnson, J. L. (1980). Specific strains of Bacteroides species in human fecal flora as measured by deoxyribonucleic acid homology. Appl Environ Microbiol 39, 407-413.

Johnson, J. L. (1994). Similarity analysis of DNAs. In Methods for General and Molecular Bacteriology, pp. 665-682. Edited by 
P. Gerhardt, R. G. E. Murray, W. A. Wood \& N. R. Krieg. Washington, DC: American Society for Microbiology.

Junca, P., Saillard, C., Tully, J. G., Garcia-Jurado, O., DegorceDumas, J. R., Mouches, C., Vignault, J. C., Vogel, R., McCoy, R. \& other authors (1980). Charactérisation de spiroplasmes isolés d'insectes et de fleurs de France continentale, de Corse et du Maroc. Proposition pour une classification des spiroplasmas. $C R$ Sceances Acad Sci D 290, 1209-1212 (in French).

Kämpfer, P., Buczolits, S., Albrecht, A., Busse, H.-J. \& Stackebrandt, E. (2003). Towards a standardized format for the description of a novel species (of an established genus): Ochrobactrum gallinifaecis sp. nov. Int J Syst Evol Microbiol 53, 893-896.

Keswani, J. \& Whitman, W. B. (2001). Relationship of $16 \mathrm{~S}$ rRNA sequence similarity to DNA hybridization in prokaryotes. Int J Syst Evol Microbiol 51, 667-678.

Knox, C. L., Giffard, P. \& Timms, P. (1998). The phylogeny of Ureaplasma urealyticum based on the $m b a$ gene fragment. Int J Syst Bacteriol 48, 1323-1331.

Konai, M., Clark, E. A., Camp, M., Koch, A. L. \& Whitcomb, R. F. (1996). Temperature ranges, growth optima, and growth rates of Spiroplasma (Spiroplasmataceae, class Mollicutes) species. Curr Microbiol 32, 314-319.

Kong, F. \& Gilbert, G. L. (2004). Postgenomic taxonomy of human ureaplasmas - a case study based on multiple gene sequences. Int $J$ Syst Evol Microbiol 54, 1815-1821.

Kong, F., James, G., Ma, Z., Gordon, S., Wang, B. \& Gilbert, G. L. (1999). Phylogenetic analysis of Ureaplasma urealyticum: support for the establishment of a new species, Ureaplasma parvum. Int J Syst Bacteriol 49, 1879-1889.

Kong, F., Ma, Z., James, G., Gordon, S. \& Gilbert, G. L. (2000). Molecular genotyping of human Ureaplasma species based on multiple-banded antigen (MBA) gene sequences. Int J Syst Evol Microbiol 50, 1921-1929.

Koski, L. B. \& Golding, G. B. (2001). The closest BLAST hit is often not the nearest neighbor. J Mol Evol 52, 540-542.

Lan, R. \& Reeves, P. R. (2001). When does a clone deserve a name? A perspective on bacterial species based on population genetics. Trends Microbiol 9, 419-424.

Lapage, S. P., Sneath, P. H. A., Lessel, E. F., Skerman, V. B. D., Seeliger, H. P. R. \& Clark, W. A. (editors) (1992). International Code of Nomenclature of Bacteria (1990 Revision). Washington, DC: American Society for Microbiology.

Leach, R. H. (1976). The inhibitory effect of arginine on growth of some mycoplasmas. J Appl Bacteriol 41, 259-264.

Leach, R. H. (1983). Preservation of mycoplasma cultures and culture collections. In Methods in Mycoplasmology, vol. 1, pp. 197-204. Edited by S. Razin \& J. G. Tully. New York: Academic Press.

Leach, R. H., Ernø, H. \& MacOwan, K. J. (1993). Proposal for designation of F38-type caprine mycoplasmas as Mycoplasma capricolum subsp. capripneumoniae subsp. nov. and consequent obligatory relegation of strains currently classified as M. capricolum (Tully, Barile, Edward, Theodore, and Ernø 1974) to an additional new subspecies, $M$. capricolum subsp. capricolum subsp. nov. Int J Syst Bacteriol 43, 603-605.

Lemcke, R. M. (1965). A serological comparison of various species of mycoplasma by an agar gel double-diffusion technique. J Gen Microbiol 38, 91-100.

Lin, J.-S. \& Kass, E. H. (1974). Serological reactions of Mycoplasma hominis: differences among mycoplasmacidal, metabolic inhibition, and growth agglutination tests. Infect Immun 10, 535-540.

Love, D. N., Johnson, J. L., Jones, R. F. \& Bailey, M. (1985). Comparison of Bacteroides zoogleoformans strains isolated from soft tissue infections in cats with strains from periodontal disease in humans. Infect Immun 47, 166-168.

Ludwig, W. \& Schleifer, K. H. (1994). Bacterial phylogeny based on $16 \mathrm{~S}$ and 23S rRNA sequence analysis. FEMS Microbiol Rev 15, 155-173.

Ludwig, W. \& Schleifer, K. H. (1999). Phylogeny of bacteria beyond the $16 \mathrm{~S}$ rRNA standard. ASM News 65, 752-757.

Ludwig, W., Strunk, O., Klugbauer, S., Weizenegger, W., Neumaier, J., Bachleitner, M. \& Schleifer, K. H. (1998). Bacterial phylogeny based on comparative sequence analysis. Electrophoresis 19, 554-568.

MacAdoo, T. O. (1993). Nomenclatural literacy. In Handbook of New Bacterial Systematics, pp. 339-358. Edited by M. Goodfellow \& A. G. O'Donnell. New York: Academic Press.

Maidak, B. L., Olsen, G. J., Larsen, N., Overbeek, R., McCaughey, M. J. \& Woese, C. R. (1997). The RDP (Ribosomal Database Project). Nucleic Acids Res 25, 109-110.

Manchee, R. J. \& Taylor-Robinson, D. (1968). Haemadsorption and haemagglutination by mycoplasmas. J Gen Microbiol 50, 465-478.

Maniloff, J. (1992). Phylogeny of mycoplasmas. In Mycoplasmas: Molecular Biology and Pathogenesis, pp. 549-559. Edited by J. Maniloff, R. N. McElhaney, L. R. Finch \& J. B. Baseman. Washington, DC: American Society for Microbiology.

Mayr, E. (1970). Populations, Species, and Evolution: an Abridgment of Animal Species and Evolution, abridged edition. Cambridge, MA: The Belknap Press of Harvard University Press.

McElwain, M. C., Chandler, D. K. F., Barile, M. F., Young, T. F., Tryon, V. V., Davis, J. W., Jr, Petzel, J. P., Chang, C.-J., Williams, M. V. \& Pollack, J. D. (1988). Purine and pyrimidine metabolism in Mollicutes species. Int J Syst Bacteriol 38, 417-423.

McIntosh, M. A., Deng, G., Zheng, J. \& Ferrell, R. V. (1992). Repetitive DNA sequences. In Mycoplasmas: Molecular Biology and Pathogenesis, pp. 363-376. Edited by J. Maniloff, R. N. McElhaney, L. R. Finch \& J. B. Baseman. Washington, DC: American Society for Microbiology.

Miles, R. J. (1992). Catabolism in mollicutes. J Gen Microbiol 138, $1773-1783$.

Miles, R. J. \& Nicholas, R. (editors) (1998). Mycoplasma Protocols (Methods in Molecular Biology, vol. 104). Totowa, NJ: Humana Press.

Minion, F. C., Lefkowitz, E. J., Madsen, M. L., Cleary, B. J., Swartzell, S. M. \& Mahairas, G. G. (2004). The genome sequence of Mycoplasma hyopneumoniae strain 232, the agent of swine mycoplasmosis. J Bacteriol 186, 7123-7133.

Mouches, C., Menara, A., Tully, J. G. \& Bové, J. M. (1982). Polyacrylamide gel analysis of spiroplasmal proteins and its contribution to the taxonomy of spiroplasmas. Rev Infect Dis $\mathbf{4}$ (Suppl.), S141-S147.

Mouches, C., Candresse, T., McGarrity, G. J. \& Bove, J. M. (1983). Analysis of spiroplasma proteins: contribution to the taxonomy of group IV spiroplasmas and the characterization of spiroplasma protein antigens. Yale J Biol Med 56, 431-437.

Murray, A. E., Lies, D., Li, G., Nealson, K., Zhou, J. \& Tiedje, J. M. (2001). DNA/DNA hybridization to microarrays reveals gene-specific differences between closely related microbial genomes. Proc Natl Acad Sci U S A 98, 9853-9858.

Navas-Castillo, J., Laigret, F., Tully, J. G. \& Bové, J.-M. (1992). Le mollicute Acholeplasma florum possède un gène du système phosphoénolpyruvate sucre-phosphotransférase et il utilize UGA comme codon tryptophane. C R Acad Sci III 315, 43-48 (in French).

Neimark, H. C. (1970). Division of mycoplasmas into subgroups. J Gen Microbiol 63, 249-263.

Neimark, H. \& Carle, P. (1995). Mollicute chromosome size determination and characterization of chromosomes from uncultured mollicutes. In Molecular and Diagnostic Procedures in Mycoplasmology, 
vol. 1, Molecular Characterization, pp. 119-131. Edited by S. Razin \& J. G. Tully. New York: Academic Press.

Neimark, H. C. \& Lange, C. S. (1990). Pulsed-field electrophoresis indicates full-length mycoplasma chromosomes range widely in size. Nucleic Acids Res 18, 5443-5448.

Nur, I., LeBlanc, D. \& Tully, J. G. (1987). Short, interspersed and repetitive DNA sequences in Spiroplasma species. Plasmid 17, 110-116.

Oshima, K., Kazikawa, S., Nishigawa, H., Jung, H. Y., Wei, W., Suzuki, S., Arashida, R., Nakata, D., Miyata, S. \& other authors (2004). Reductive evolution suggested from the complete genome sequence of a plantpathogenic phytoplasma. Nat Genet 36, 27-29.

Papazisi, L., Gorton, T. S., Kutish, G., Markham, P. F., Browning, G. F., Nguyen, D. K., Swartzell, S., Madan, A., Mahairas, G. \& Geary, S. J. (2003). The complete genome sequence of the avian pathogen Mycoplasma gallisepticum strain $\mathrm{R}_{\text {low. Microbiology } 149,2307-2316 .}$

Pellegrin, J. L., Maugein, J., Clerc, M. T., Leng, B., Bové, J. M. \& Bébéar, C. (1990). Activity of rifampin against mollicutes, clostridia and L-forms. Zentralbl Bakteriol Suppl 20, 810-812.

Persson, A., Jacobsson, K., Frykberg, L., Johannson, K.-E. \& Poumarat, F. (2002). Variable surface protein Vmm of Mycoplasma mycoides subsp. mycoides small colony type. J Bacteriol 184, 3712-3722.

Pettersson, B., Tully, J. G., Bölske, G. \& Johansson, K.-E. (2000). Updated phylogenetic description of the Mycoplasma hominis cluster (Weisburg et al. 1989) based on 16S rDNA sequences. Int J Syst Evol Microbiol 50, 291-301.

Pollack, J. D. (1992). Carbohydrate metabolism and energy conservation. In Mycoplasmas: Molecular Biology and Pathogenesis, pp. 181-200. Edited by J. Maniloff, R. N. McElhaney, L. R. Finch \& J. B. Baseman. Washington, DC: American Society for Microbiology.

Pollack, J. D. (1997). Mycoplasma genes: a case for reflective annotation. Trends Microbiol 5, 413-419.

Pollack, J. D., McElwain, M. C., DeSantis, D., Manolukas, J. T., Tully, J. G., Chang, C.-J., Whitcomb, R. F., Hackett, K. J. \& Williams, M. V. (1989). Metabolism of members of the Spiroplasmataceae. Int J Syst Bacteriol 39, 406-412.

Pollack, J. D., Banzon, J., Donelson, K., Tully, J. G., Davis, J. W., Jr, Hackett, K. J., Agbanyim, C. \& Miles, R. J. (1996a). Reduction of benzyl viologen distinguishes genera of the class Mollicutes. Int J Syst Bacteriol 46, 881-884.

Pollack, J. D., Williams, M. V., Banzon, J., Jones, M. A., Harvey, L. \& Tully, J. G. (1996b). Comparative metabolism of Mesoplasma, Entomoplasma, Mycoplasma, and Acholeplasma. Int J Syst Bacteriol 46, 885-890.

Pollack, J. D., Williams, M. V. \& McElhaney, R. N. (1997). The comparative metabolism of the mollicutes (mycoplasmas), the utility for taxonomic classification and the relationship of putative gene annotation and phylogeny to enzymatic function. Crit Rev Microbiol 23, 269-354.

Pollack, J. D., Li, Q. \& Pearl, D. K. (2005). Taxonomic utility of a phylogenetic analysis of phosphoglycerate kinase proteins of Archaea, Bacteria, and Eukaryota: insights by Bayesian analyses. Mol Phylogenet Evol 35, 420-430.

Poveda, J. B. (1998). Biochemical characteristics in mycoplasma identification. Methods Mol Biol 104, 69-78.

Poveda, J. B. \& Nicholas, R. J. (1998). Serological identification of mycoplasmas by growth and metabolism inhibition tests. Methods Mol Biol 104, 105-111.

Pyle, L. E., Corcoran, L. E., Cocks, B. G., Bergemann, A. D., Whitley, J. C. \& Finch, L. R. (1988). Pulsed field electrophoresis indicates largerthan-expected sizes for mycoplasma genomes. Nucleic Acids Res 16, 6015-6025.
Raccach, M., Rottem, S. \& Razin, S. (1975). Survival of frozen mycoplasmas. Appl Microbiol 30, 167-171.

Razin, S. (1968). Mycoplasma taxonomy studied by electrophoresis of cell proteins. J Bacteriol 96, 687-694.

Razin, S. (1983). Urea hydrolysis. In Methods in Mycoplasmology, vol. 1, pp. 351-353. Edited by S. Razin \& J. G. Tully. New York: Academic Press.

Razin, S. \& Cirillo, V. P. (1983). Sugar fermentation. In Methods in Mycoplasmology, vol. 1, pp. 337-343. Edited by S. Razin \& J. G. Tully. New York: Academic Press.

Razin, S. \& Tully, J. G. (1970). Cholesterol requirement of mycoplasmas. J Bacteriol 102, 306-310.

Regassa, L. B., Stewart, K. M., Murphy, A. C., French, F. E., Lin, T. \& Whitcomb, R. F. (2004). Differentiation of group VIII spiroplasma strains with sequences of the 16S-23S rDNA intergenic spacer region. Can J Microbiol 50, 1061-1067.

Reich, P. R., Somerson, N. L., Hubner, C. J., Chanock, R. M. \& Weissman, S. M. (1966). Genetic differentiation by nucleic acid homology. I. Relationships among Mycoplasma species of man. J Bacteriol 92, 302-310.

Renaudin, J. \& Bové, J. M. (1994). SpV1 and SpV4, spiroplasma viruses with circular, single-stranded DNA genomes and their contribution to the molecular biology of spiroplasmas. Adv Virus Res 44, 429-463.

Renaudin, J., Pascarel, M. C., Saillard, C., Chevalier, C. \& Bové, J. M. (1986). Chez les spiroplasmes le codon UGA n'est pas non sens et semble coder pour le tryptophane. C R Acad Sci III 303, 539-540 in French

Rikihisa, Y., Kawahara, M., Wen, B., Kociba, G., Fuerst, P., Kawamore, F., Suto, H., Shibata, S. \& Futohashi, M. (1997). Western immunoblot analysis of Haemobartonella muris and comparison of $16 \mathrm{~S}$ rRNA gene sequences of $H$. muris, $H$. felis and Eperythrozoon suis. J Clin Microbiol 35, 823-829.

Robertson, J. A. \& Stemke, G. W. (1979). Modified metabolic inhibition test for serotyping strains of Ureaplasma urealyticum. J Clin Microbiol 9, 673-676.

Robertson, J. A., Howard, L. A., Zinner, C. L. \& Stemke, G. W. (1994). Comparison of 16S rRNA genes within the T960 and parvo biovars of ureaplasmas isolated from humans. Int J Syst Bacteriol 44, 836-838.

Robertson, J. A., Stemke, G. W., Davis, J. W., Jr, Harasawa, R., Thirkell, D., Kong, F., Shepard, M. C. \& Ford, D. K. (2002). Proposal of Ureaplasma parvum sp. nov. and emended description of Ureaplasma urealyticum (Shepard et al. 1974) Robertson et al. 2001. Int J Syst Evol Microbiol 52, 587-597.

Robinson, I. M. (1983). Culture media for anaeroplasmas. In Methods in Mycoplasmology, vol. 1, pp. 159-162. Edited by S. Razin \& J. G. Tully. New York: Academic Press.

Rodwell, A. W. \& Rodwell, E. S. (1978). Relationships between strains of Mycoplasma mycoides subspp. mycoides and capri studied by twodimensional gel electrophoresis of cell proteins. J Gen Microbiol 109, 259-263.

Rose, D. L. \& Tully, J. G. (1983). Detection of $\alpha$-D-glucosidase: hydrolysis of esculin and arbutin. In Methods in Mycoplasmology, vol. 1, pp. 385-389. Edited by S. Razin \& J. G. Tully. New York: Academic Press.

Rosengarten, R. \& Yogev, D. (1996). Variant colony surface antigenic phenotypes within mycoplasma strain populations: implications for species identification and strain standardization. J Clin Microbiol 34, 149-158.

Rosselló-Mora, R. (2006). DNA-DNA reassociation methods applied to microbial taxonomy and their critical evaluation. In Molecular 
Identification, Systematics, and Population Structure of Prokaryotes, pp. 23-50. Edited by E. Stackebrandt. Berlin: Springer-Verlag.

Rosselló-Mora, R. \& Amann, R. (2001). The species concept for prokaryotes. FEMS Microbiol Rev 25, 39-67.

Rottem, S. (1972). Differentiation of sterol-requiring from sterolnonrequiring mycoplasmas by amphoterican B. Appl Microbiol 23, 659-660.

Saillard, C., Carle, P., Bové, J. M., Bébéar, C., Lo, S. C., Shih, J. W., Wang, R. Y., Rose, D. L. \& Tully, J. G. (1990). Genetic and serologic relatedness between Mycoplasma fermentans strains and a mycoplasma recently identified in tissues of AIDS and non-AIDS patients. Res Virol 141, 385-395.

Saitou, N. \& Nei, M. (1987). The neighbor-joining method: a new method for reconstructing phylogenetic trees. Mol Biol Evol 4, 406-425.

Sasaki, Y., Ishikawa, J., Yamashita, A., Oshima, K., Kenri, T., Furuya, K., Yoshino, C., Horino, A., Shiba, T. \& other authors (2002). The complete genomic sequence of Mycoplasma penetrans, an intracellular bacterial pathogen in humans. Nucleic Acids Res 30, 5293-5300.

Shepard, M. C., Lunceford, C. D., Ford, D. K., Purcell, R. H., TaylorRobinson, D., Razin, S. \& Black, F. T. (1974). Ureaplasma urealyticum gen. nov., sp. nov.: proposed nomenclature for the human T (Tstrain) mycoplasmas. Int J Syst Bacteriol 24, 160-171.

Somerson, N. L., Reich, P. R., Chanock, R. M. \& Weissman, S. M. (1967). Genetic differentiation by nucleic acid homology. III. Relationships among mycoplasma, L-forms, and bacteria. Ann NY Acad Sci 143, 9-20.

Stackebrandt, E. \& Goebel, B. M. (1994). Taxonomic note: a place for DNA-DNA reassociation and 16S rRNA sequence analysis in the present species definition in bacteriology. Int J Syst Bacteriol 44, 846-849.

Stackebrandt, E., Frederiksen, W., Garrity, G. M., Grimont, P. A. D., Kämpfer, P., Maiden, M. C., Nesme, X., Rosselló-Mora, R., Swings, J. $\&$ other authors (2002). Report of the ad hoc committee for the reevaluation of the species definition in bacteriology. Int J Syst Evol Microbiol 52, 1043-1047.

Stakenborg, T., Vicca, J., Butaye, P., Maes, D., De Baere, T., Verhelst, R., Peeters, J., de Kruif, A., Haesebrouck, F. \& Vaneechoutte, M. (2005). Evaluation of amplified rDNA restriction analysis (ARDRA) for the identification of Mycoplasma species. BMC Infect Dis 5, 46. doi:10.1186/1471-23345-46

Stephens, E. B., Aulakh, G. S., Rose, D. L., Tully, J. G. \& Barile, M. F. (1983a). Intraspecies genetic relatedness among strains of Acholeplasma laidlawii and of Acholeplasma axanthum by nucleic acid hybridization. J Gen Microbiol 129, 1929-1934.

Stephens, E. B., Aulakh, G. S., Rose, D. L., Tully, J. G. \& Barile, M. F. (1983b). Interspecies and intraspecies DNA homology among established species of Acholeplasma, a review. Yale J Biol Med 56, 729-735.

Swofford, D. L. (1998). PAUP - Phylogenetic Analysis Using Parsimony (*and other methods), version 4. Sunderland, MA: Sinauer.

Swofford, D. L., Olsen, G. J., Wadell, P. J. \& Hillis, D. M. (1996). Phylogenetic inference. In Molecular Systematics, pp. 407-514. Edited by D. M. Hillis, C. Moritz \& B. K. Mable. Sunderland, MA: Sinauer.

Taylor-Robinson, D. (1983). Metabolism inhibition tests. In Methods in Mycoplasmology, vol. 1, pp. 411-417. Edited by S. Razin \& J. G. Tully. New York: Academic Press.

Taylor-Robinson, D. \& Berry, D. M. (1969). The evaluation of the metabolic-inhibition technique for the study of Mycoplasma gallisepticum. J Gen Microbiol 55, 127-137.
Taylor-Robinson, D., Purcell, R. H., Wong, D. C. \& Chanock, R. M. (1966). A colour test for the measurement of antibody to certain mycoplasma species based upon the inhibition of acid production. J Hyg (Lond) 64, 91-104.

Teichmann, S. A. \& Mitchison, G. (1999). Is there a phylogenetic signal in prokaryote proteins? J Mol Evol 49, 98-107.

Toth, K. F., Harrison, N. \& Sears, B. B. (1994). Phylogenetic relationships among members of the class Mollicutes deduced from rps3 gene sequences. Int J Syst Bacteriol 44, 119-124.

Townsend, R. (1976). Arginine metabolism by Spiroplasma citri. J Gen Microbiol 94, 417-420.

Trachtenberg, S. (1998). Mollicutes - wall-less bacteria with internal cytoskeletons. J Struct Biol 124, 244-256.

Trüper, H. G. (1996). Help! Latin! How to avoid the most common mistakes while giving Latin names to newly discovered prokaryotes. Microbiologia 12, 473-475.

Trüper, H. G. (1999). How to name a prokaryote? Etymological considerations, proposals and practical advice in prokaryote nomenclature. FEMS Microbiol Rev 23, 231-249.

Trüper, H. G. (2007). Neo-Latinists worldwide willing to help microbiologists. Int J Syst Evol Microbiol 57, 1164-1166.

Tully, J. G. (1983a). Cloning and filtration techniques for mycoplasmas. In Methods in Mycoplasmology, vol. 1, pp. 173-177. Edited by S. Razin \& J. G. Tully. New York: Academic Press.

Tully, J. G. (1983b). Bacterial and fungal inhibitors in mycoplasma culture media. In Methods in Mycoplasmology, vol. 1, pp. 205-209. Edited by S. Razin \& J. G. Tully. New York: Academic Press.

Tully, J. G. (1983c). Tests for digitonin sensitivity and sterol requirement. In Methods in Mycoplasmology, vol. 1, pp. 355-362. Edited by S. Razin \& J. G. Tully. New York: Academic Press.

Tully, J. G., Bové, J. M., Laigret, F. \& Whitcomb, R. F. (1993). Revised taxonomy of the class Mollicutes: proposed elevation of a monophyletic cluster of arthropod-associated mollicutes to ordinal rank (Entomoplasmatales ord. nov.), with provision for familial rank to separate species with nonhelical morphology (Entomoplasmataceae fam. nov.) from helical species (Spiroplasmataceae), and emended descriptions of the order Mycoplasmatales, family Mycoplasmasmataceae. Int J Syst Bacteriol 43, 378-385.

Vandamme, P., Pot, B., Gillis, M., De Vos, P., Kersters, K. \& Swings, J. (1996). Polyphasic taxonomy, a consensus approach to bacterial systematics. Microbiol Rev 60, 407-438.

Watson, H. L., Blalock, D. K. \& Cassell, G. H. (1990). Variable antigens of Ureaplasma urealyticum containing both serovar-specific and serovar-cross-reactive epitopes. Infect Immun 58, 3679-3688.

Watson, H. L., Zheng, X. \& Cassell, G. H. (1993). Structural variations and phenotypic switching of mycoplasmal antigens. Clin Infect Dis $\mathbf{1 7}$ (Suppl. 1), S183-S186.

Wayadande, A. C. \& Fletcher, J. (1995). Transmission of Spiroplasma citri lines and their ability to cross gut and salivary gland barriers within the leafhopper vector Circulifer tenellus. Phytopathology 85, 1256-1259.

Wayne, L. G., Brenner, D. J., Colwell, R. R., Grimont, P. A. D., Kandler, O., Krichevsky, M. I., Moore, L. H., Moore, W. E. C., Murray, R. G. E. \& other authors (1987). Report of the ad hoc committee on reconciliation of approaches to bacterial systematics. Int J Syst Bacteriol 37, 463-464.

Weisburg, W. G., Tully, J. G., Rose, D. L., Petzel, J. P., Oyaizu, H., Yang, D., Mandelco, L., Sechrest, J., Lawrence, T. G. \& other authors (1989). A phylogenetic analysis of the mycoplasmas: basis for their classification. J Bacteriol 171, 6455-6467.

Westberg, J., Persson, A., Holmberg, A., Goesmann, A., Lundeberg, J., Johansson, K.-E., Pettersson, B. \& Uhlén, M. (2004). The genome 
sequence of Mycoplasma mycoides subsp. mycoides SC type strain PG ${ }^{\mathrm{T}}$, the causative agent of contagious bovine pleuropneumonia (CBPP). Genome Res 14, 221-227.

Whitcomb, R. F. (1977). International Committee on Systematic Bacteriology Subcommittee on the Taxonomy of Mycoplasmatales. Minutes of the interim meeting, 22 September 1976, London, United Kingdom. Int J Syst Bacteriol 27, 392-394.

Whitcomb, R. F. (1983). Culture media for spiroplasmas. In Methods in Mycoplasmology, vol. 1, pp. 147-158. Edited by S. Razin \& J. G. Tully. New York: Academic Press.

Whitcomb, R. F. (1984a). International Committee on Systematic Bacteriology Subcommittee on the Taxonomy of Mollicutes. Minutes of interim meetings, 2 and 5 September 1980, Custer, South Dakota. Int J Syst Bacteriol 34, 358-360.

Whitcomb, R. F. (1984b). International Committee on Systematic Bacteriology Subcommittee on the Taxonomy of Mollicutes. Minutes of the interim meeting, 30 August and 6 September 1982, Tokyo, Japan. Int J Syst Bacteriol 34, 361-365.

Whitcomb, R. F. \& Hackett, K. J. (1987). Cloning by limiting dilution in liquid media, an improved alternative for cloning mollicute species. Isr J Med Sci 23, 517.

Whitcomb, R. F. \& Hackett, K. J. (1996). Identification of mollicutes from insects. In Molecular and Diagnostic Procedures in Mycoplasmology, vol. 2, pp. 313-322. Edited by J. G. Tully \& S. Razin. New York: Academic Press.

Whitcomb, R. F., Bové, J. M., Chen, T. A., Tully, J. G. \& Williamson, D. L. (1987). Proposed criteria for an interim serogroup classification for members of the genus Spiroplasma (class Mollicutes). Int J Syst Bacteriol 37, 82-84.

Whitcomb, R. F., French, F. E., Tully, J. G., Gasparich, G. E., Rose, D. L., Carle, P., Bové, J. M., Henegar, R. B., Konai, M. \& other authors (1997). Spiroplasma chrysopicola sp. nov., Spiroplasma gladiatoris sp. nov., Spiroplasma helicoides sp. nov., and Spiroplasma tabanidicola sp. nov., from tabanid (Diptera: Tabanidae) flies. Int J Syst Bacteriol 47, 713-719.

Williams, C. O. \& Wittler, R. G. (1971). Hydrolysis of aesculin and phosphatase production by members of the order Mycoplasmatales which do not require sterol. Int J Syst Bacteriol 21, 73-77.

Williamson, D. L. \& Whitcomb, R. F. (1975). Plant mycoplasmas: a cultivable spiroplasma causes corn stunt disease. Science 188, 1018-1020.

Williamson, D. L. \& Whitcomb, R. F. (1983). Special serological tests for spiroplasma identification. In Methods in Mycoplasmology, vol. 1, pp. 249-259. Edited by S. Razin \& J. G. Tully. New York: Academic Press.
Williamson, D. L., Whitcomb, R. F. \& Tully, J. G. (1978). The spiroplasma deformation test, a new serological method. Curr Microbiol 1, 203-207.

Williamson, D. L., Tully, J. G. \& Whitcomb, R. F. (1979). Serological relationships of spiroplasmas as shown by combined deformation and metabolism inhibition tests. Int J Syst Bacteriol 29, 345-351.

Williamson, D. L., Whitcomb, R. F., Tully, J. G., Gasparich, G. E., Rose, D. L., Carle, P., Bové, J. M., Hackett, K. J., Adams, J. R. \& other authors (1998). Revised group classification of the genus Spiroplasma. Int J Syst Bacteriol 48, 1-12.

Winston, J. E. (1999). Describing Species: Practical Taxonomic Procedure for Biologists. New York: Columbia University Press.

Wise, K. S. (1993). Adaptive surface variation in mycoplasmas. Trends Microbiol 1, 59-63.

Wise, K. S., Yogev, D. \& Rosengarten, R. (1992). Adaptive surface variation in mycoplasmas. In Mycoplasmas: Molecular Biology and Pathogenesis, pp. 473-489. Edited by J. Maniloff, R. N. McElhaney, L. R. Finch \& J. B. Baseman. Washington, DC: American Society for Microbiology.

Woese, C. R. (1987). Bacterial evolution. Microbiol Rev 51, 221-271.

Woese, C. R., Maniloff, J. \& Zablen, L. B. (1980). Phylogenetic analysis of the mycoplasmas. Proc Natl Acad Sci U S A 77, 494-498.

Wolf, M., Muller, T., Dandekar, T. \& Pollack, J. D. (2004). Phylogeny of Firmicutes with special reference to Mycoplasma (Mollicutes) as inferred from phosphoglycerate kinase amino acid sequence data. Int J Syst Evol Microbiol 54, 871-875.

Yamao, F., Muto, A., Kawauehi, Y., Iwami, M., Iwagami, S., Azumi, V. \& Osawa, S. (1985). UGA is read as tryptophan in Mycoplasma capricolum. Proc Natl Acad Sci U S A 82, 2306-2309.

Ye, F., Laigret, F., Carle, P. \& Bové, J. M. (1995). Chromosomal heterogeneity among various strains of Spiroplasma citri. Int J Syst Bacteriol 45, 729-734.

Yogev, D., Levisohn, S. \& Razin, S. (1989). Genetic and antigenic relatedness between Mycoplasma gallisepticum and Mycoplasma synoviae. Vet Microbiol 19, 75-84.

Yoshida, S., Fujisawa, A., Tsuzaki, Y. \& Saitoh, S. (2000). Identification and expression of a Mycoplasma gallisepticum surface antigen recognized by a monoclonal antibody capable of inhibiting both growth and metabolism. Infect Immun 68, 3186-3192.

Yugi, H., Suzuki, M., Shizuo, S. \& Ozaki, Y. (1973). Freeze-drying of mycoplasma. Cryobiology 10, 464-467.

Zeigler, D. R. (2003). Gene sequences useful for predicting relatedness of whole genomes in bacteria. Int J Syst Evol Microbiol 53, 1893-1900. 